\title{
Las obras de Feliciano de Silva en los inventarios de las bibliotecas hispánicas del Siglo de Oro: lectura y presencia
}

\author{
José Luis Gonzalo Sánchez-Molero \\ Universidad Complutense de Madrid
}

\section{RESUMEN}

La producción literaria de Feliciano de Silva, autor de una segunda Celestina y de una amplia saga de libros de caballerías en la senda del Amadís, tuvo una importante difusión en el siglo XVI y primeras décadas del siguiente. En este artículo se aborda la presencia de su obra en los inventarios y catálogos españoles e indianos durante dicho periodo. Para ello se analiza la tipología social de los lectores de las obras de Silva, la distribución comercial de sus ejemplares y sus formas de lectura. También se indaga, a la luz de los lectores, sobre las vinculaciones del propio autor con las cortes española y portuguesa. Y se analiza cómo la presencia y posteriores ausencias de sus obras en los inventarios, permite comprobar el papel de los libros de caballerías como lectura de consumo y entretenimiento, sufriendo los avatares de laa modas lectoras..

PALABRAS ClAVE: Feliciano de Silva. Literatura caballeresca español. Inventarios de libros. Lectura.

Feliciano de Silva's works in the inventories of the Hispanic libraries of the Golden Age: reading and stock

\section{ABSTRACT}

The literary production of Feliciano de Silva, author of a second Celestina and a wide saga of books of chivalry in the path of the Amadis, had an important diffusion in the XVI century and first decades of the following one. This article deals with the presence of his work in Spanish and Indian inventories and catalogues during this period. For this purpose, the social typology of the readers of Silva's works is analysed, as well as the commercial distribution of his copies and their forms of reading. It also investigates, in the light of the readers, the author's own links with the Spanish and Portuguese courts. And it is analysed how the presence and subsequent absences of his works in the inventories, allows to verify the role of the books of chivalry as reading of consumption and entertainment, suffering the vicissitudes of the reading fashions.

KEY WORDS: Feliciano de Silva. Books of chivalry. Book's inventories. Reading. 
Tratar sobre la fortuna y fama de las obras escritas por Feliciano de Silva (c. 1491-1554) entre los siglos XVI y XVII es casi tanto como abordar las mismas cuestiones con respecto al conjunto de género caballeresco en España. Tras la publicación del Amadís de Gaula (1508) fueron tan numerosas las ediciones y reediciones que Silva hizo de sus ampliaciones del texto amadisiano, que ambos conceptos pueden llegar a confundirse. El escritor español se reveló como un atento conocedor de las apetencias lectoras de sus contemporáneos, cuasi hechizados por la temática caballeresca del Amadís de Gaula, y supo ejercer como un continuador ejemplar. A su pluma se deben las narraciones de sus descendientes literarios, publicadas bajo los títulos de: Lisuarte de Grecia (Sevilla, 1514), Noveno Libro del Amadís de Gaula, o Amadís de Grecia (Cuenca, 1530), Rogel de Grecia (Medina del Campo, 1535) y Don Florisel de Niquea, en varias partes (Valladolid, 1532, Medina del Campo, 1535 y Salamanca, 1551). También escribió Silva una Segunda Celestina (Medina del Campo, 1534) y el autobiográfico Sueño de Feliciano (1544). Su prolífica pluma se vio acompañada por el aplauso del público y la atención de los impresores. Sus obras se editaron tanto en España como en Italia, y se tradujeron a varios idiomas europeos. Como nada de esto es desconocido por el lector, de manera que remitimos a aquellos autores que han tratado de manera detallada la fortuna editorial de Feliciano de Silva ${ }^{1}$.

$\mathrm{Su}$ éxito como escritor en la época contrasta, sin embargo, con las escasas informaciones de que disponemos para reconstruir su biografía ${ }^{2}$. Miembro de una familia ilustre e hidalga de Ciudad Rodrigo, fue hijo de Tristán de Silva, al que habitualmente se hace referencia como cronista de Carlos V, si bien fue nombrado para tal oficio por los Reyes Católicos en 1485, y no por su nieto el emperador, en especial porque parece que Tristán ya había fallecido hacia $1503^{3}$. Desde 1523 Feliciano ejerció como regidor de su ciudad natal, con carácter vitalicio, falleciendo en la misma localidad en 1554. Se había casado, a pesar de la oposición de su familia, con una mujer de origen judeoconverso, Gracia Fe, hija de cierto Hernando de Caracena, lo que puede que le retrajera de participar de manera más activa en la vida política y cortesana de la época, donde la limpieza de sangre se iba imponiendo de manera paulatina. Poco más se sabe sobre su vida, su formación y sus gustos literarios. Al morir solo se registra

1.- Sobre las obras de Feliciano de Silva, véase Eisenberg y Marín Pina (2000: 239-243).

2.- Recordemos los trabajos pioneros de Emilio Cotarelo y Mori (1921), Narciso Alonso Cortés (1933), Erasmo Buceta (1931), Sidney P. Cravens (1976), Consolación Baranda (1988), Ma. Carmen Marín Pina (1991a), Javier Martín Lalanda (2002) y José Emilio Sales Dasí (2004-2005).

3.- Nombramiento de Mayor de Guzmán como curadora de la persona y bienes de sus hijos, Isabel, María y Feliciano de Silva por el fallecimiento de su padre, Tristán de Silva (Ciudad Rodrigo. 7 de noviembre de 1503). Archivo Histórico de la Nobleza, YELTES, C. 3, D. 29. 
la existencia en su casa de un arca llena de libros en romance y en latín, sin especificar sus títulos, lo que tanto nos habría ayudado a comprender sus fuentes literarias ${ }^{4}$. Curiosamente, en este estudio que dedicamos a analizar la presencia de sus obras en los inventarios hispanos del Siglo de Oro, el propio inventario postmortem de sus bienes casi nada nos puede aportar, excepto esa escueta referencia.

No en vano, y como veremos a continuación, nuestro interés se centra en analizar la presencia de las obras de Silva en las bibliotecas del Siglo de Oro, identificando en lo posible las ediciones que aparecen en dicha documentación, por un parte, y por la otra, tratando de definir si a través de esta presencia se puede confirmar la existencia de unos cánones sociales de lectura, vinculados a la producción literaria de Feliciano de Silva. El período por abordar es muy amplio, pues la primera edición de este autor se publicó en 1514 (Lisuarte de Grecia) y la última reedición de uno de sus libros, en italiano, se publicó en 1629 (La historia di Amadis de Grecia, Cavallier dell'Ardente Spada), en Venecia. En 1604-05 Miguel de Cervantes, a poco de empezar la redacción del Ingenioso Hidalgo don Quijote, escribe que Alonso Quijano llevó a su casa cuantos libros de caballerías pudo comprar, "y de todos, ningunos le parecían tan bien como los que compuso el famoso Feliciano de Silva, porque la claridad de su prosa y aquellas intrincadas razones suyas le parecían de perlas» (Quijote I, cap. I). Este y otros juicios cervantinos sobre este autor han determinado en gran parte nuestra percepción sobre cómo fue recibida en la época su pléyade de Lisuartes, Amadises, Rogeles y Floriseles, pero la opinión de Cervantes no puede considerase como generalizada, ni tampoco como la existente a lo largo de un período tan extenso. Además, las obras de Silva tuvieron lectores muy diversos, no sólo desde el punto de vista del género o del estamento social, sino también desde la perspectiva del origen nacional de sus lectores, españoles, franceses, italianos, etc. La amplia y compleja difusión de sus libros ofrece, en consecuencia, un panorama que, a la fuerza, debe ser emprendido por el investigador con la certeza de que ha de ser plural. Una manera de asomarnos a dicha pluralidad es a través de los inventarios donde sus obras aparecen.

\section{Los inventarios como fuente de investigación}

Cuando se emprende un estudio sobre los contenidos de bibliotecas, suele ser habitual recurrir al análisis de inventarios y catálogos, como parte de una metodología casi inevitable 5 . En el ámbito español, Infantes (1999 y 1997), Pedraza (1999) y Prieto Bernabé (2004) han escrito nota-

\footnotetext{
4.- Alonso Cortés (1933: 396).

5.- Chartier (1994), Chevalier (1976) y Derolez (1979).
} 
bles reflexiones sobre esta cuestión. La metodología fue iniciada por Henry-Jean Martin, en su Livre, pouvoirs et société à Paris au XVIIe siècle (1969). Martin trabajó con inventarios de bibliotecas personales, habitualmente de carácter post-morten y con el objetivo de conocer la identidad y características de los lectores, o de la sociedad o grupo social en la que se integraban. La técnica investigadora de Martin fue criticada por Furio Diaz y Adriana Lay en los años 70 del siglo pasado. Ambos disintieron sobre la conveniencia de aplicar métodos cuantitativos a la historia de la cultura: el primero se refería a la dificultad de identificar al poseedor con las ideas contenidas en el libro (Díaz, 1972 y 1966); la segunda (Lay, 1990), a que la metodología cuantitativa debía completarse con el recurso a otras fuentes de información y el sometimiento de los datos obtenidos al contexto social investigado. En todo este debate se percibe que el problema de fondo no radica tanto en el contenido de las fuentes empleadas, sino en el contenido y alcance de las mismas. Un libro poseído, no siempre es sinónimo de un libro leído; tampoco su presencia en un inventario testamentario garantiza que perteneciera al difunto; $y$, desde luego, aunque fuera suyo, esto no permite colegir que estuviera de acuerdo con las ideas que la obra pudiera representar. En todo caso, concluyamos que la publicación y análisis de inventarios de libros sigue siendo, a pesar del debate sobre el alcance real de su utilidad, una línea de investigación plenamente consolidada que ha saltado desde la publicación de los resultados en papel a su difusión en internet. Un ejemplo de esto último es la IBSO: Inventarios y Bibliotecas del Siglo de Oro, proyecto que se inserta en las actividades del SIELAE (Seminario Interdisciplinar para el Estudio de la Literatura Áurea Española) de la Universidad de La Coruña ${ }^{6}$.

No menos se ha debatido sobre la definición de términos como "catálogo» e "inventario». Aunque el uso indistinto de ambas palabras sea habitual entre los estudiosos de la cultura escrita, Concepción Rodríguez Parada (2007) ha tratado recientemente de "fijar en la medida de lo posible el significado general y a la vez 'distintivo' de catálogo e inventario para mostrar qué tipo de luz pueden aportar al conocimiento de la historia del libro y de las bibliotecas». Nosotros emplearemos únicamente como fuente los inventarios. Y queremos explicar el porqué, si bien ya lo hemos hecho en otra ocasión (Gonzalo Sánchez Molero, 2015). En nuestra opinión, el catálogo de una biblioteca constituye siempre una fuente organizada y ordenada de sus contenidos, ya que su función no es tanto la de demostrar la propiedad de los libros, sino la facilitar su acceso a los lectores. Un catálogo es, pues, una fuente de información esencial para un bibliotecario o para los usuarios de la biblioteca, y por ello se redactan de una manera metódica. Un inventario, en cambio, carece habitualmente de dicha exhaustividad. Su función es distinta, en la mayor parte de los

\section{6.- Una presentación de IBSO por Fernández Travieso y López Poza (2011).}


casos los inventarios solo se elaboraron para acreditar la propiedad de los libros, o su ubicación temporal durante un transporte o venta. Esta propensión a la temporalidad favorece que los autores de estos documentos tiendan a ser menos exhaustivos. Y es que, para quienes los redactaron no había error alguno en los contenidos de estos inventarios. Cumplían con su función, es cierto que fugaz, pero la única para la que habían sido concebidos. Como el resto de la documentación archivística, los inventarios no se produjeron en su momento con el objeto de servir como fuente para una posterior investigación histórica. Como destaca José Manuel Pedraza (1999), la documentación archivística aporta únicamente la información que era pertinente al fin que la originó, y, en consecuencia, ésta no suele coincidir con los fines de la investigación.

Un catálogo ofrece, en cambio, una información en apariencia cerrada, donde los datos de los libros se uniformizan para ajustarse a unas normas. Los catálogos, por tanto, suelen ser un excelente instrumento para conocer cómo se concebía la cultura en una determinada época. En cambio, por su propia función fugaz o temporal un inventario contiene siempre una información más "fresca» y variada. El inventario, ciertamente suele ser solo una lista de bienes, y su única función es la de garantizar la propiedad o integridad de su contenido (nunca es un catálogo, donde se identifican los contenidos para su uso y localización), pero su propia indefinición en la descripción de los contenidos hace de ellos una fuente preciosa para el investigador, ya que reflejan mucho mejor los cambios y los usos de los libros. Ni siquiera cuando un inventario carece de datos sobre el dueño de los libros, o incluso de fecha, su contenido carece de interés. Al contrario, puede convertirse en un objeto de investigación micro-histórica relevante. No ha de sorprender, por tanto, que, para el tema que nos ocupa, las aportaciones han sido numerosas. Existe un amplio elenco de trabajos sobre inventarios y libros en la España del Siglo de Oro, en cuyo análisis los historiadores de nuestra historia del libro y de la imprenta se han movido con gran perspicacia, comodidad y utilidad. Se trata de una fuente de la que han bebido Trevor Dadson, Clive Griffin, Pedro Cátedra, Vicente Bécares, Víctor Infantes, Manuel Peña, José Manuel Prieto, Manuel Pedraza, Pedro Rueda, Anastasio Rojo, Díez Borque ${ }^{7}$, y esto por solo citar algunos nombres. En muchos de los trabajos previos de estos autores deberemos ir recalando en cada una de las siguientes páginas.

7.- Suyas han sido las aportaciones más recientes, y que conforman además un conjunto bien organizado, ya que han partido de proyectos de investigación dirigidos por el profesor Díez Borque (2010), (2012), (2015), (2016). 


\section{Los libros de caballerías como lectura de entretenimiento y canon literario}

Un primer elemento para comprender la exitosa difusión de las obras de Feliciano de Silva estuvo en el género escogido por éste para desarrollar gran parte de su creatividad: la narrativa caballeresca. Es bien sabido que este género literario tuvo un prodigioso auge en toda Europa tras la publicación del Amadís de Gaula (Zaragoza, 1508). Los impresores de la época percibieron con rapidez la atracción que esta narrativa generó en los lectores, y la aprovecharon para potenciar un mercado que hasta entonces no habían explorado de manera suficiente, y que no era otro que el de la literatura de entretenimiento a gran escala, y con un mercado amplio y popular. En general, hasta entonces las lecturas de ocio (con tiradas pequeñas y formatos menores) se habían entintado como «menudencias», el Amadís, en cambio, puso de manifiesto que una obra literaria, concebida inicialmente para su consumo aristocrático, había penetrado en los gustos lectores de todos las capas sociales y estamentales. Esto tuvo una clara implicación en la conversión del género literario caballeresco en un género editorial, cuyas características (diseño de portadas, tipografías, formato en folio, etc.,) han sido analizadas con detalle por varios autores, por lo que no insistiremos en ello.

Una de las primeras evidencias del éxito de los libros de caballerías, y de su impacto en la configuración de las mentalidades culturales del Quinientos, se detecta en las constantes y agrias quejas de los humanistas hacia este tipo de literatura. No sólo en España, donde desde Vives a Cervantes se ha podido elaborar un amplio repertorio de críticas y de duras quejas sobre la lectura de estos libros ${ }^{9}$, sino también en Francia, en Italia y en otros países europeos, como ejemplifican las denuncias de Montaigne y de Posevino ${ }^{10}$. Pedro Mexia, en su Silva de varia lección, arremete contra «las trufas y mentiras de Amadis, y de Lisuartes, y Clarianes, y otros portentos: que con tanta razon deurian ser desterrados de España: como cosa contagiosa y dañosa a la república, pues tan mal hazen gastar el tiempo a los autores y lectores de ellos. Y lo que es peor, que dan muy malos exemplos, y muy peligrosos para las costumbres». Y poco después, Diego Gracián de Alderete, en el prólogo a su traducción castellana de Jenofonte, justifica su labor:

\footnotetext{
8.- Lucía Megías (1998) y (2000).

9.- Véase Bataillon (1966: 622). En la nota correspondiente, Bataillon ya proporcionó una lista de estas críticas.

10.- Sarmati (1996).
} 
porque a lo menos embotare con la licion desta obra a los lectores Españoles el gusto del entendimiento para leer los libros de mentiras y patrañas, que llaman de cauallerias, de que ay más abundancia en nuestra España que en ningunos otros reynos, auiendo de auer menos: pues no siruen de otra cosa, sino de perder el tiempo y desautorizar los otros buenos libros verdaderos de buena doctrina y prouecho. Porque las patrañas difformes y desconcertadas que en estos libros de mentiras se leen, derogan el credito y las verdaderas hazañas que se leen en las historias de verdad ${ }^{11}$.

Ahora bien, los libros de caballerías no deben entenderse únicamente desde esta perspectiva negativa que, desde los erasmistas hasta Cervantes, se nos transmitido, ligada a su consumo como una lectura popular y propia de indoctos, sino que también debemos poner en el otro platillo de la balanza que la narrativa caballeresca ejerció un indudable papel en la plasmación de un canon literario en la lengua castellana. Su estilo narrativo y su uso del lenguaje escrito conformaron un modo de escribir y de leer, cuya influencia (no lo olvidemos) llegará hasta el Quijote, como su autor reconocerá12 ${ }^{2}$ Como escribe Aguilar Perdomo (2005: 47), a la que parafraseamos, los libros de caballerías fueron una de las ficciones más exitosas de la prosa renacentista. Leídos o escuchados, manoseados o aprendidos de memoria, y vituperados por los humanistas que exhortaban a hombres y mujeres a no alterar su ánimo con la lectura de estas obras de entretenimiento, los libros de caballerías pusieron a funcionar a toda máquina las imprentas españolas para cubrir la demanda de un público diverso, apasionado por seguir las aventuras de los hijos y nietos de Amadís de Gaula, la saga del Caballero del Febo, o de Belianís de Grecia, uno de los libros favoritos de Carlos V. Feliciano de Silva, a este respecto, fue un constante innovador del género caballeresco. A lo largo de sus cinco continuaciones amadisianas, Silva se revela como un autor en una búsqueda continua de todos aquellos aditamentos que pueden contribuir a la obtención de una fórmula narrativa que satisfaga plenamente a sus lectores ${ }^{13}$.

De igual manera que en España el estilo literario de los libros de caballerías favoreció la evolución y desarrollo de la lengua romance, la castellana en gran medida, el mismo fenómeno se produjo en Francia, donde en 1540 salió a la luz la primera edición francesa del Amadís en la traducción de Herberay des Essarts. Este traductor seguiría, incansable, cumpliendo con su labor de difusión del ciclo en lengua francesa, de tal modo que cada año un nuevo libro traducido pudiese llegar hasta las manos del

\footnotetext{
11.- Ambas citas, de Mexía y Gracián, han sido tomadas de Karl Kohut (2002: 178).

12.- Cacho Blecua (1979).

13.- Véase Sales Dasí (2005: 121), García Álvarez (2015a) y (2015b).
} 
ávido lector de libros de caballerías: en 1541 está disponible el segundo libro, en 1542 el tercero, en 1543 el cuarto, en 1544 el quinto, el libro sexto (que se corresponde con el séptimo del ciclo original) en 1545 , y el libro séptimo en 1546 (estos últimos siguiendo las continuaciones castellnas de Feliciano de Silva). El libro octavo es la última contribución de Nicolas Herberay des Essarts en pro de la traducción del ciclo amadisiano: su primera edición está fechada de $1548^{14}$. Estas ediciones francesas se difundieron abundantemente ilustradas, a diferencia de las españolas, especialmente en el caso de las del Amadis de Grèce. Existen ediciones impresas en París (las primeras y las más numerosas), en Lyon (que aparecieron veinte años después y que no contienen grabados) y las que salieron de las prensas de Amberes.

En Italia, como es sabido, durante unos años el principal interés de los impresores estuvo en publicar ediciones en castellano del Amadís (Roma, 1519, Venecia, 1534), Esplandián (Roma, 1525), Palmerín (Venecia, 1526 y 1534), etc., con el propósito de vender los ejemplares en la propia España o entre los muchos españoles que residían en la península itálica. A partir de 1544, sin embargo, el tipógrafo veneciano Michele Tramezzino advirtió el interés por estas obras entre el público italianos, y lanzó al mercado una serie de traducciones italianas. Pietro Lauro de Módena y Mambrino Roseo de Fabriano fueron quienes trasladaron las hazañas de los descendientes de Amadís de Gaula a su idioma natal ${ }^{15}$. Roseo prestaría especial atención a las continuaciones amadisinas de Feliciano de Silba. A su pluma se debe El segundo libro de Lisuarte de Grecia, obra impresa por primera vez en Venecia en 1564 por Michele Tramezzino, y en la cual se relatan nuevas aventuras de Lisuarte de Grecia, su tío Perión de Gaula y otros caballeros. Parte de las aventuras de Lisuarte reltadas en este libro transcurren, sorprendentemente, en Japón. El segundo libro de Lisuarte alcanzó una popularidad considerable, ya que fue reimpreso en Venecia en 1586, 1599,1610 y 1630.

\section{Las obras de Feliciano de Silva en los inventarios}

Tan notable producción editorial, ya fuera en España, como también en Italia y en Francia, se detecta (como no podía ser de otra manera) en los inventarios de la época, y si seguimos el camino de cada una de estas ediciones desde el taller de imprenta hasta las manos del lector, este periplo por los inventarios debemos iniciarlo en la documentación conservada sobre impresores, mercaderes de libros y libreros de la época. Es en este primer tipo de fuentes, vinculadas a los inventarios, donde de una ma-

\footnotetext{
14.- Botero García (2010).

15.- Bognolo (2008).
} 
nera más evidente se pone de manifiesto el efecto comercial que la gran demanda de libros de caballerías tuvo en la primera mitad del siglo XVI, así como el papel que las obras de Silva ejerció en la configuración de este mercado editorial. A diferencia de otros autores de narrativa caballeresca, el regidor de Ciudad Rodrigo nunca abandono el cultivo de este género. Muy al contrario, perseveró en la composición de varios libros de caballerías, creando una saga familiar en la que los lectores de la época pudieran deleitarse con las hazañas y amores de los descendientes, en varias generaciones, de Amadís de Gaula. Y, lo más importante, siempre encontró un impresor que publicara sus originales. Esta circunstancia evidencia que Silva no sólo entendió los gustos literarios de sus contemporáneos, sino que también comprendió cómo funcionaba el mercado editorial en el Quinientos español. ¿Dónde adquirió Silva su aguda comprensión sobre el funcionamiento de este negocio? Todo parece indicar que fue en Salamanca, ya que allí debió estudiar hacia 1500/1510. En sus aulas no resulta extraño que concibiera su primer libro de caballerías, el Lisuarte (1514). Salamanca, con sus librerías e imprentas era un buen lugar para aprender no sólo Teología o Derecho, sino también afición por la literatura.

Sea como fuere, uno de los aspectos donde mejor se observa la percepción de Silva sobre el negocio librario es en su dominio de las reglas de la competencia editorial. Debe recordase que el Lisuarte de Silva se encontró con la presencia en el mercado de un segundo Lisuarte, obra del bachiller Díaz (Sevilla, 1526). Silva, a quien la aparición de esta obra disgustó muchísimo, continuó en Amadís de Grecia (1530) la acción del primer Lisuarte, pasando por alto la obra de su competidor. Es muy posible que Silva, en 1526, tuviera ya avanzada la composición del Amadís de Grecia, por lo que debió temer que el público se inclinase por leer la serie Florisandosegundo Lisuarte, planteada por Díaz, y no la serie narrativa EsplandiánLisuarte, que Silva había propuesto en 1514. Si esto hubiera ocurrido, el primer Lisuarte, que desde entonces no había sido reimpreso, habría caído en el olvido, perdiendo interés la publicación de su Amadís de Grecia. Se comprende que en esta obra Silva dedicara furibundas críticas al texto de su rival. El éxito editorial del Amadís de Grecia y de sus continuaciones en Florisel de Niquea y Rogel de Grecia, aseguró el fracaso del segundo Lisuarte $y$, por tanto, el monopolio literario de Silva en esta temática. Cuando de nuevo se vio amenazado por otro autor, Pedro de Luján, se atrevió a continuar su Rogel de Grecia en Silves de la Selva (1546), duodécimo libro de la serie amadisiana, Silva reaccionó severas críticas a esta obra. Su Cuarta Parte de Don Florisel de Niquea, publicada en 1551, fue una respuesta comercial contundente, ya que en su argumento se ignoraba por completo la existencia de la obra de Luján.

No se ha localizado, por ahora, documentación notarial suficiente que nos atestigüe los detalles de sus relaciones con impresores, mercaderes de libros y libreros- Solo hallamos que a su muerte se encontraban en- 
tre sus papeles documentos referentes a cantidades que le adeudaba el impresor salmantino, Andrea de Portionaris (Alonso Cortes, 1933). Afortunadamente, el rastro de sus ediciones en los inventarios de estos nos permite comprender algunas cuestiones. Empecemos con un dato curioso. La primera vez que una de sus obras, Lisuarte de Grecia, aparece en un inventario de carácter mercantil no es en España, como sería lógico suponer, sino en América. En 1521, en la ciudad de Santo Domingo, se realizó el inventario de varias cajas embaladas que pertenecían a cierta doña Inés de la Peña, esposa de un espadero llamado Francisco de Pedraza. Repletas de libros, todo da a entender que se trataba de una remesa procedente de la península, para su venta a los españoles que se habían asentado en las Antillas. No en vano, las cajas contenían numerosas obras repetidas, especialmente cartillas de gramática de las que había noventa y seis ejemplares, además de tres docenas del libro devoto Perla preciosa. Junto con estos, aparecen también un ejemplar del Lisuarte, el séptimo libro de la serie de los Amadises. Le acompañaban otros libros de la misma temática: dos Pigmaleones, dos libros de Oliveros de Castilla, y un Amadís de Gaula (Mira Caballos, 1994). El hecho de que la obra de Silva hubiera sido publicada muy poco tiempo antes, en 1514, resulta un dato significativo acerca de su difusión. Se comprende, en este contexto, que en 1531 el Consejo de Indias optara por prohibir que los libros de caballerías se vendieran en Indias. Su temática no parecía adecuada para los objetivos evangelizadores que se pretendían, ni como lectura para los nativos americanos.

Si recordamos que el Lisuarte había sido impreso por Juan Varela de Salamanca en Sevilla, la temprana presencia de ejemplares en la isla de Santo Domingo tiene una explicación clara. En la primera mitad del siglo XVI Sevilla fue el principal centro productor y distribuidor de libros en Castilla. Esto otorgó a sus impresores una gran capacidad para determinar los géneros editoriales de muchos productos, en especial los destinados al lector español y, en gran parte, también, al americano. Entre estos impresores destacó uno de origen alemán, Jacobo Cromberger, el primero de una familia dedicada durante tres generaciones al negocio del libro (Griffin, 1991). Como es sabido, a lo largo de la primera mitad del siglo XVI los Cromberger se convirtieron en los mayores productores de libros de caballerías, siendo los mejores promotores de este género editorial. Feliciano de Silva recurriría a sus prensas para publicar casi todas sus obras. De su Chronica del muy valiente y esforçado Principe y Cauallero de la ardiente espada Amadis de Grecia, hijo de Lisuarte de Grecia, Emperador de Constantinopla, y de Trapisonda, y Rey de Rodas, tras su primera edición en Burgos, entintada por Juan de Junta (a costa de Juan de Spinosa), en 1535, encontramos ediciones en Sevilla, por Juan Cromberger, en 1542, y por Jácome Cromberger, en 1549. De su Don Florisel de Niquea, de nuevo comprobamos que, tras ser impresa la primera edición en Valladolid, por Nicolás Tierri (1532), las dos siguientes ediciones se publicaron por los citados Juan y Jácome Crom- 
berger, en Sevilla, en 1536 y 1546 respectivamente. Y de su Chronica de los famosos y esforçados caualleros Lisuarte de Grecia, hijo de Esplandian Emperador de Constantinopla, y de Perion de Gaula hijo del valiente y esforçado cauallero Amadis de Gaula Rey de la gran Bretaña, tras su primera edición sevillana en 1514, volvió a reeditarse en la ciudad andaluza por Dominico de Robertis en 1543 y en 1548, y por Jácome Cromberger en 1550.

Como era de esperar, tan estrecha vinculación se detecta en la documentación de los Cromberger. En el inventario del almacén de Jacobo (1528), estudiado por Griffin (1988a), se registra la existencia de «162 ciprinos de amadiz", que el autor británico identifica con ejemplares de la edición crombergiana de El séptimo libro de Amadís en el cual se trata de los grandes hechos en armas de Lisuarte de Grecia (Sevilla, 1525); y de otros "24 sitimos [de Amadís] faltos» (Griffin, 1988a: 201). Cuando en 1540 falleció Juan Cromberger, en el inventario de su almacén encontramos de nuevos ejemplares de varias obras de Silva, ya autor consagrado para los lectores de la época. Estaban «ciento y veynte onzenos de Amadis», más otros 11 del «onzeno de amadis» y otros 40 de la misma obra, que Griffin identifica con ejemplares de una edición crombergiana desconocida, o procedentes de la edición impresa en Medina del Campo (1535) ${ }^{16}$. También encontramos en su almacén varios ejemplares de «ardiente espada» o del «nouenos de amadis", que deben corresponder con ejemplares de El noveno libro de Amadís que es la crónica del muy valiente y esforzado príncipe y caballero de la ardiente espada Amadís de Gregia, hijo de Lisuarte de Grecia ${ }^{17}$. De nuevo, la primera edición crombergiana conocida es de 1546, por lo debía tratarse de ejemplares procedentes de las ediciones de Cuenca (1530) o de Burgos (1535), adquiridos por el impresor sevillano para su comercialización en Indias. La misma circunstancia se da con los cuatro ejemplares que almacenaba de "don florisel de niquea». No es hasta 1546 cuando se tiene constancia de una edición crombergiana, por lo que cabe suponer que estos volúmenes procedían de la edición vallisoletana de $1532^{18}$. Sí se entintaron en los prelos de Cromberger los 10 ejemplares de «septimo amadis», de los que sabemos hubo una edición sevillana en $1525^{19}$, y que podrían corresponderse además con restos sin vender de aquellos 162 ejemplares almacenados por Jacobo años atrás (1528).

Los libros de caballerías no tuvieron la misma presencia editorial durante la segunda mitad de la centuria. Los efectos de la política inquisitorial y regia sobre la producción libraria española (Pragmática de 1558 e Índice de libros prohibidos de 1559) provocaron una clara contracción en la producción editorial, que se vio acompañada de un cierto agotamiento de

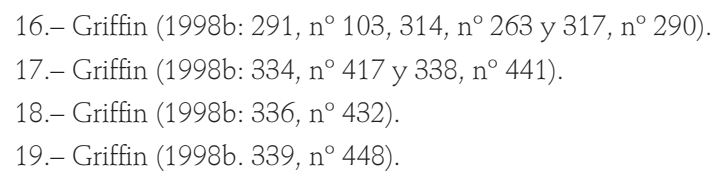


los lectores con respecto a la temática caballeresca. A mediados de la década de los sesenta e inicios de la de los ochenta del siglo XVI se aprecian rebrotes en la publicación de los libros de caballerías, tanto de los escritos por Feliciano de Silva como de otros autores. El librero y mercader de libros Benito Boyer financió muchas de estas ediciones, de modo que en el inventario de los bienes que dejó a su muerte en 1592, aparecen un total de quinientos veinticinco ejemplares de distintos libros de caballerías (Bécares Botas e Iglesias, 1992), pero a fines de la centuria estas obras ya no se imprimen, e incluso se opta por la copia manuscrita para su difusión, o por la venta de ejemplares impresos de segunda o tercera mano. Su venta debió de ser muy abundante en esta época, y el propio Cervantes se hace eco de esta circunstancia en el Quijote, en aquel fragmento de su inicio, donde narra su compra compulsiva de libros de caballerías y en especial de un autor, Feliciano de Silva:

Es, pues, de saber, que este sobredicho hidalgo, los ratos que estaba ocioso (que eran los más del año) se daba a leer libros de caballerías con tanta afición y gusto, que olvidó casi de todo punto el ejercicio de la caza, y aun la administración de su hacienda; y llegó a tanto su curiosidad y desatino en esto, que vendió muchas hanegas de tierra de sembradura, para comprar libros de caballerías en que leer; y así llevó a su casa todos cuantos pudo haber dellos; y de todos ningunos le parecían tan bien como los que compuso el famoso Feliciano de Silva: porque la claridad de su prosa, y aquellas intrincadas razones suyas, le parecían de perlas; y más cuando llegaba a leer aquellos requiebros y cartas de desafío, donde en muchas partes hallaba escrito: la razón de la sinrazón que a mi razón se hace, de tal manera mi razón enflaquece, que con razón me quejo de la vuestra fermosura, y también cuando leía: los altos cielos que de vuestra divinidad divinamente con las estrellas se fortifican, y os hacen merecedora del merecimiento que merece la vuestra grandeza. (Quijote, I, 1)

Puesto que las ediciones eran muy escasas, el lector de la época entendía a principios del siglo xvi que Alonso Quijano había comprado su biblioteca caballeresca en librerías con ejemplares de segunda mano. Los inventarios de varios libreros nos permiten constatar tal suposición. Bécares Botas (2007) reproduce y analiza los inventarios de veinte libreros de dicha ciudad, entre 1530 y 1601, pero sorprendentemente solo recoge 
ejemplares de obras de Silva en uno de ellos, fechado en $1592^{20}$. ¿Cómo interpretar tan escasa presencia, cuando las tipo-bibliografías nos atestiguan decenas de ediciones en dichos años? Quizás la respuesta está en que Bécares estudia en su mayor parte inventarios relacionados con liquidación o reparto de los libros en almacén. De este modo, si las obras de Silva tenían tan amplia demanda como parece atestiguar la constante reedición de las mismas, se comprende que todos los ejemplares se hubieran vendido. No es, por tanto, su ausencia una señal de falta de interés lector, todo lo contrario. Ya no quedaban ejemplares a la venta, pues lectores de la época, con perfil semejante al descrito por Cervantes para Alonso Quijano, ya se habían hecho con ellos mucho antes. Su rápida venta tras ser editados, en tiradas cada vez más pequeñas a partir del reinado de Felipe II, explican esta ausencia, más bien escasez, en las librerías.

Otro ejemplo. En 1606 descubrimos que el librero madrileño Cristóbal López tenía en su establecimiento una selección nutrida de libros de caballerías, pero casi siempre como ejemplares únicos. Varios ejemplares eran obras de Feliciano de Silva, un "Don florisel de niquea", tasado en doce reales, "Otro don florisel», en diez reales (Dadson, 1998: 215-216, 286), un "Amadis de grecia", tasado en dos reales y un "Don rroxel de grecia», en doce ${ }^{21}$. Si atendemos a las fechas inmediatamente previas de sus ediciones (c. 1560 para Rogel de Grecia, 1588 para Florisel y 1596 para Amadís de Grecia), parece bastante evidente que López sólo tenía ya en su librería ejemplares viejos, de segunda mano. En 1648 el panorama en el inventario de la librería madrileña de Alonso Pérez de Montalbán era paupérrimo ${ }^{22}$. Solo hallamos 1 ejemplar del "Florisel de Niquea», ningún otro libro de caballerías aparece citado. Los gustos españoles en narrativa habían cambiado de manera espectacular.

Sin embargo, al otro extremo de la Monarquía Hispánica, en la ciudad peruana de Lima, encontramos que los libreros Pedro Durango o Flecher y Cristóbal Hernández tenían en sus tiendas (inventariadas en 1603 y 1619) una amplia oferta de libros de caballerías, y para nuestra sorpresa con mayor número de ejemplares que en la Corte española: 27 ejemplares de Florisel de Niquea, 12 del Floranís de Castilla, 10 del Palmerin de Oliva, 9 del Amadís de Gaula, 9 de las Sergas de Esplandián, 8 de Selidón de Iberia, 5 de Lisuarte, 4 del Amadís de Grecia y, por último, 4 ejemplares del Caba-

20.- En el inventario de la librería de Diego Rodríguez y de Ana de Vitoria (1592). Bécares (2007: 385) señala que en este establecimiento había muchos libros en romance, y entre ellos destacan "los de caballerías, muchos de ellos faltos, sin duda porque eran ejemplares de segunda mano muy leídos». Y en las obras de Feliciano de Silva: "Un Don Florisel primera parte en papel quatro Rs» $y$ "Dos Don Florisel primera parte en pergamino diez y seys reales» (2007: 406).

21.- Dadson (1998: 278, 279, 280, 286, 287, 492-493). Recoge todas las ediciones de Feliciano de Silva.

22.- Cayuela (2005) 
llero Asisio ${ }^{23}$. El predominio de las obras salidas de la pluma de Feliciano de Silva es evidente, y también es probable que la mayor parte fueran libros «viejos». Del Florisel las últimas ediciones se habían publicado en 1551 (libro XI amadisiano), en 1568 (libro XI) y en 1588 (libro X). Si entendemos que los cinco ejemplares del Lisuarte eran de Silva, entonces la última edición fue entintada en Zaragoza, en 1587. Sólo los ejemplares de la edición del Amadís de Grecia, obra publicada por última vez en Lisboa en 1596, podrían ser recientes. Mas, ipor qué había más ejemplares en Lima que en Madrid de estas obras? La respuesta está, por una parte, en la competencia. Como es lógico, en la villa y corte castellana había muchas más librerías que en la ciudad virreinal, y, por tanto, los ejemplares disponibles se repartían. Flecher y Hernández, en este contexto, podían aspirar a monopolizar la venta de libros, e incluso es posible que el segundo hubiera comprado en 1603 el stock que Flecher había dejado sin vender a su muerte. Pero, por otra parte, existía otro aspecto a valorar: la temporalidad del comercio indiano, limitado por el sistema de flotas, favorecía que se aprovechara cada flota para enviar al mercado americano el mayor número posible de libros, o de otras mercancías. Si atendemos al inventario de los libros que Martín Sánchez de Solís, embarcó en la flota a Tierra Firme en 1601, se observa el gran número de ejemplares de libros de caballerías registrados: 9 ejemplares del "Amadís de Gaula», 19 del "Amadís de Grecia», de Silva, 1 "Belianís», 2 "Espejo de Caballeros», 138 ejemplares del "Florisel de Niquea», de Silva, 80 del «Primaleón», 2 "Sergas de Espladián», y 1 «Lisuarte», que (por el mayor número de ediciones), debemos suponer que era también el publicado por Feliciano de Silva, y no el de Díaz ${ }^{24}$. De todos los autores, Silva destaca por la variedad y la cantidad de volúmenes de sus obras que se llevaban para vender en Indias.

De los inventarios mercantiles, de impresores y de libreros, los siguientes materiales de este tipo que debemos rastrear son los personales, es decir, los de los lectores que habrían adquiridos sus libros de caballerías, y en particular los de Feliciano de Silva. Se trata de un material que ha sido estudiado con cierta amplitud, como ya sabemos. En su extenso trabajo sobre la lectura en Madrid en el Siglo de Oro, Prieto Bernabé (2004: 278, nota 31), localizó un total de 71 inventarios que incluían libros de caballerías, con un total de 166 entradas. Se ha considerado que se trata, en proporción con las ediciones y tiradas, de un número bastante escaso, pero también hay que valorar que es muy posible que los poseedores se deshiciesen de obras que habían leído en su juventud, por no encontrar en ellos el mismo deleite, o por ser ya libros viejos. Su reiterada lectura, individual o colectiva, llegaba a deteriorarlos, impidiendo su conservación. Un deterioro que se acrecentaba con la costumbre de prestarlos. El

23.- González Sánchez (1997: 673).

24.- Citamos por Diez Borque (2008: 95-96). 
análisis realizado por Díez Borque (2007) sobre 67 bibliotecas entre los años de 1600 y 1650 arroja resultados parecidos, siendo muy pocos los conjuntos librescos donde se conservan novelas y siempre en muy escasa proporción. Si bien, dentro de estas bibliotecas donde se conservan novelas son los libros de caballerías, las novelas artúricas y los géneros afines los que más frecuentemente aparecen.

La presencia de las obras de Feliciano de Silva se aprecia en todas las categorías sociales, y en este recorrido por la estructura estamental española, empezaremos con la realeza. Y no sólo porque reyes, reinas, príncipes e infantas estuvieran en la cúspide de aquella sociedad, sino también porque muchos libros de caballerías les fueron dedicados. El propio Silva ofreció la Parte IV de su Florisel a María de Austria, hija de Carlos V (1551), pero no fue un caso único: Gonzalo Fernández de Oviedo dirigió en 1519 su Claribalte a Fernando de Aragón, duque de Calabria; en 1545 el joven Felipe II recibió de su autora, Beatriz Bernal, la dedicatoria del Cristalián de España; y la segunda parte del Clarián de Landanís fue puesto bajo el patronazgo del rey Juan III de Portugal, por su autor Jerónimo López (1550). Ahora bien, no siempre los inventarios evidencian la lectura de libros de caballerías por estos monarcas y sus familiares. Es el caso, por ejemplo, de Carlos V, monarca caballeresco por excelencia. En 1517, cuando viajó por vez primera vez a Castilla desde los Países Bajos, se elaboró una descripción de los bienes que trajo consigo, entre ellos una selecta biblioteca de viaje, que contenía libros devotos, libros de historia, como Las Décadas de Tito Livio y la Crónica de Francia, de Monstrelet, y también varios romans caballerescos en francés, como el Giron le Courtois, el Olivier de Castilla y el Huon de Burdeos, en copias manuscritas. No parece que conociera por entonces los primeros libros de caballerías castellanos, pero en poco tiempo el César se dejaría ganar por estos, abandonando su gusto por los viejos relatos caballerescos franco-borgoñones, demasiado medievales. Como otros lectores de la época, el Amadís le cautivó, y es sabido que cuando en 1527 nació su primogénito, el príncipe Felipe, el monarca organizó un gran torneo inspirado en pasajes y personajes de la obra de Rodríguez de Montalvo. En los años siguientes su afición no decreció, es bien conocido con respecto a la publicación del Belianís de Grecia, que su autor Jerónimo Fernández, decidió continuar su obra en una tercera y cuarta partes, según afirmaba porque tenía noticias del contento del Emperador con sus dos primeras entregas ${ }^{25}$. Sin embargo, ni el Amadís, ni el Belianís, ni tampoco alguno de los libros de Feliciano de Silva, aparecen en los inventarios de sus bienes. Sólo el Theverdank de su abuelo Maximiliano, o El caballero determinado, de Olivier de la Marche, 
merecieron una presencia destacada en su biblioteca personal ${ }^{26}$. Y estas obras no eran libros de caballerías, sino poemas caballerescos.

La misma circunstancia se produce con su esposa, la emperatriz Isabel de Portugal. En una anécdota recogida por Luis Zapata, quien fue paje de la soberana, se cuenta que la dama María Manuel, leyendo ante Carlos V e Isabel un libro de caballerías durante la siesta, se inventó el siguiente encabezamiento: "Capítulo de cómo Don Cristóbal Osorio, hijo del marqués de Villanueva, casaría con Doña María Manuel, dama de la Emperatriz, reina de España, si el Emperador para después de los días de su padre le hiciese merced de la encomienda de Estepa». Divertidos por la ocurrencia, los soberanos acordaron concederle la merced solicitada de una manera tan origina ${ }^{27}$. ¿Fue la emperatriz lectora de libros de caballerías? Lo cierto es que en su biblioteca sólo hallamos un libro de esta temática, la Demanda del Santo Grial, y esta obra (como en el caso de Carlos V) tampoco puede considerarse como una pieza del género caballeresco, sino más como un libro de ficción ligado a la materia de Bretaña. En los inventarios elaborados tras la muerte de la emperatriz (1539) no se indica si su ejemplar era manuscrito o impreso, pero el hecho de que se vendiera en almoneda, a un bajo precio (dos reales), parece indicar que se trataba de un libro de molde, muy probablemente un ejemplar de la edición impresa en Toledo, por Juan de Villaquirán (1515), o de la reedición efectuada por Juan Varela de Salamanca, en Sevilla (1535): La demanda del sancto Grial: Con los marauillosos fechos de La[n] çarote y de Galaz su hijo.

No es hasta 1547 cuando disponemos de la primera evidencia de la lectura de una obra de Feliciano de Silva por un miembro de la dinastía. Fue entonces cuando se compró una colección de libros de caballerías para el príncipe Felipe, futuro rey Felipe II. Hasta entonces sus preceptores humanistas, algunos de ellos erasmistas ${ }^{28}$, le habían vedado la lectura de estas obras, consideradas como perniciosas. Tampoco (debe añadirse) los libros en castellano habían tenido una presencia importante en las lecturas escolares del heredero, entre las que siempre se había primado la lectura de obras en latín y en griego. Es por todo esto, que el joven Felipe debió recibir con cierta ansiedad los libros siguientes, comprados por Gil Sánchez de Bazán, su criado, en mayo de 1547. Tras «Los quatro del Amadís», un "Rreinaldos» y un "Splandian», figuraba ya un "Don florisel de Niquea» ${ }^{29}$. Parece evidente la intención de que el príncipe conociera el ciclo del Amadís, que Feliciano de Silva tanto había ayudado a desarrollar en los años anteriores. No fueron los únicos libros de esta temática que

26.- Gonzalo Sánchez Molero (2000).

27.- Zapata de Chaves (1949).

28.- Gonzalo Sánchez Molero (2013).

29.- Libranza a Gil Sánchez de Bazán (1547-48) por ocho libros comprados en Madrid. (AGS. CSR. Leg. 36. Fol. 1º, fol. 267v). Véase Gonzalo Sánchez Molero (1998). 
debieron llegar al príncipe, pues en esta selección falta el VI de los libros de Amadís, el Florisando de Ruy Páez de Ribera (Salamanca, 1510). Quizás esta ausencia se debiera porque ya había un ejemplar en palacio, prestado o regalado, al heredero, o propiedad de alguno de sus cortesanos. Asimismo, en un papelito roto, guardado dentro de este mismo Libro de cuentas del príncipe, se conserva un billete con cuentas, roto, sin datar ${ }^{30}$, y en el que aparecen algunas de las obras compradas por Bazán en 1547, y junto con estas obras la anotación: «Esfera mundi rruxiana con esfera maior y a mas de..». En nuestra opinión, se trata de una referencia a $\mathrm{La}$ dozena parte del invencible cavallero Amadis de Gaula que trata de los grandes hechos en armas del esforçado cauallero Don Silves de la Selva con el fin de las guerras Ruxianas, junto con el nascimiento de los temidos caualleros Esferamundi y Amadis de Astra y assi mismo de los dos esforçados principes Fortunian y Astrapalo (Sevilla, 1546), de Pedro Luján ${ }^{31}$. Como sabemos que Sánchez de Bazán compró también al heredero un ejemplar del Espejo de cauallerias que trata del conde don Roldán, de Pero López de Santa Catalina, (con edición sevillana de 1545), es probable que un ejemplar del Silves de la Selva también le fuera comprado.

¿Con qué propósito se compraron estos libros de caballerías? Con veinte años ya, desembarazado de la autoridad de sus preceptores, es muy probable que el príncipe Felipe mandara adquirirlos para entretenerse leyéndolos durante su viaje a Aragón, para presidir las Cortes de Monzón, o durante su estancia en esta localidad, cuyo adusto castillo y entorno natural, no propiciaban otras formas de ocio lúdico. Esta hipótesis no es solo verosímil, sino que parece plenamente acertada por la coincidencia temporal de la compra de estos volúmenes con la convocatoria de las Cortes $^{32}$, y porque, junto con los libros de caballerías arriba citados, se incluyó un ejemplar latino de la Genealogía de los Reyes de Aragón, de Lucio Marineo Sículo ${ }^{33}$. Es verdad que puede sorprender esta afición por la literatura caballeresca en Felipe II durante su juventud, ya que no concuerda con la imagen posterior que de él se labró como monarca, pero en estos años la retórica caballeresca estaba en alza en la Corte, y formaba parte de la construcción política del heredero como sucesor de Carlos V. Varias

\section{0.- AGS. CSR. Leg. 36. Fol. 8, [en fol. 201r].}

31.- Gonzalo Sánchez Molero (1998: no. 874).

32.- Las Cortes de Monzón convocadas el 6 de abril de 1547 para celebrarse el 23 de junio, si bien la primera sesión no tivo lugar hasta el 5 de julio y la última el 9 de diciembre de 1547.

33.- "Más pagó ocho libros, siete en rromançe que son, rreinaldos, splandian, otro de los quatro del amadis, don florisel de niquea, del preste juan de las indias en portugues, y el otro es en latin de la genelogia (sic) de los rreys de aragon». (1.607 maravedises). AGS., CSR., leg. 36, Fol. 1ㅜ, fol. 267v. Libranza a Sánchez de Bazán (Madrid, 10-may-1547). Creemos que se trataba de un ejemplar de la obra de Lucio Marineo Sículo, Pandit Aragoniae veterum primordia regum, hoc opus: et forti praelia gesta manu. Zaragoza, Jorge Coci Alemán, 1509. Fol. (Gonzalo Sánchez Molero, 1998: no. 940). 
justas, torneos y fiestas de tipo caballeresco celebraron su matrimonio con la infanta María de Portugal en 1543, y recordemos que sólo dos años después Beatriz Bernal del Castillo dedicó a Felipe su Cristalián de España (Valladolid, 1545). La apoteosis de esta propaganda cortesana y política que ligaba al futuro rey y (se creía) también emperador, se produjo durante el Felicísimo Viaje de éste a los Países Bajos. Como es sabido, las fiestas de Bins, o Binche, organizadas por su tía María de Hungría, basaron su argumento en las hazañas de Amadís de Gaula y Felipe participó en ellas representando al caballero Beltenebros.

La lectura por el joven Felipe II de un ejemplar del Florisel de Niquea, probablemente su III Parte, impresa en Sevilla (1546), se acompañó pocos años después con la dedicatoria a su hermana, la infanta María, de la edición de su IV Parte del Florisel (Salamanca, 1551). Se ha supuesto, para justificar esta dedicatoria, que Feliciano de Silva posiblemente asistió a las bodas de Felipe en Salamanca, celebradas en 1543, y a las de la infanta María con Maximiliano de Austria, celebradas en Valladolid en 1548, ciudades próximas a Ciudad Rodrigo (Cravens, 1976: 75). Silva nada aclara al respecto en el prólogo a María, reina ya de Bohemia, si bien era la primera vez que dedicaba una de sus obras a un miembro de la familia imperial. Quizás, y no era poca razón para quien había hecho de su obra literaria una especie de monopolio sobre las continuaciones amadisianas, mirara con recelo la dedicatoria de Beatriz Bernal al príncipe Felipe de su Cristalián de España. A Feliciano, además, le habrían llegado noticias de los fastuosos recibimientos que a éste se habían hecho en los Países Bajos, así como de las escenografías cortesanas basadas en los libros de caballerías. Esto, junto con las traducciones francesas de Herberay des Essarts (publicadas entre 1540 y 1546, y basadas en los textos originales de Silva), no sólo constituían un evidente reconocimiento al género caballeresco fuera de las fronteras de Castilla, también suponían la consagración de Silva como autor.

Siendo esto así, lo cierto es que, sin embargo, nos inclinamos hacia otra hipótesis. Feliciano de Silva, que hasta entonces había dedicado sus obras anteriores a hombres, nobles como el Duque de Infantado, decidió con su IV parte del Florisel dirigirse hacia el público femenino. Con la dedicatoria a María de Austria el mensaje que se lanzaba a las lectoras de la época, así como a los detractores del género caballeresco, era nítido. Mas, ¿sabía Silva si a María de Austria le gustaban las lecturas caballerescas? ¿No era muy arriesgado dedicarle su Floristán, sin tener la seguridad de que la nueva gobernadora de Castilla apreciaría el obsequio? Aunque en algún momento se ha descrito a Silva como un autor provinciano, sobre todo porque Diego Hurtado de Mendoza le motejó con aquella lapidaria frase de "Lo más que ha corrido es de Ciudad Rodrigo a Valladolid», en realidad sospechamos que Feliciano de Silva siempre estuvo contacto con la Corte castellana (fue contino de Carlos V entre 1535 y 1539), y muy 
en particular con los miembros de la Casa de las Infantas María y Juana. Debemos recordar que una parte importante de las damas y criados que servían en la Casa de las Infantas había llegado desde Portugal con la emperatriz Isabel, permaneciendo en Castilla tras su muerte en 1539, sirviendo a sus dos hijas, María y Juana. Feliciano de Silva, como su apellido delata, descendía de un noble del país vecino, Aires Gomes da Silva, señor de Fogocillo y de Aguiar, tatarabuelo de nuestro autor, quien se instaló en Ciudad Rodrigo, una ciudad fronteriza con Portugal, a finales del siglo XIv. Feliciano, quien nunca olvidó sus orígenes, trabó amistad con varios escritores portugueses, como Sá de Miranda y Bernardim Ribeiro, posiblemente desde 1530 (Cravens, 1976: 27), pero también con el poeta luso Jorge de Montemayor. Éste había llegado a Castilla en 1543, en el séquito de la princesa María de Aviz, primera esposa del príncipe Felipe, y fue asentado hacia 1545 como cantor en la capilla de sus hermanas, convirtiéndose en el "animador» de una cierta vida cultural cortesana, en la que tuvieron gran protagonismo el teatro y la literatura pastoril, temáticas ambas muy en consonancia con el carácter femenino de aquella Casa En 1548 el portugués dedicó a la infanta María su Exposición moral sobre el salmo LXXXVI del real profeta David. Este ejemplo sería seguido por Feliciano de Silva, al que Montemayor dirigió hacia 1554 una sentida Elegía, así como un Epitafio a la sepultura de Feliciano de Silva, donde se evidencia su amistad y profunda admiración mutuas. En este contexto, se comprende mejor que el príncipe Felipe o sus hermanas María y Juana fueran lectores de sus obras.

También era leído en la corte de Bruselas, donde las traducciones francesas del ciclo amadisiano de Rodríguez de Montalvo y Silva pusieron de moda los libros de caballerías españoles. En Amberes, el impresor Martín Nucio, tras una larga estancia en Castilla, también quiso facilitar la lectura del Amadís a sus compatriotas, publicando en 1546 una traducción al neerlandés de los dos primeros libros del ciclo. Junto con estos ejemplares en francés y en neerlandés, en 1551 se publicó en Lovaina una edición en castellano, Los quatros libros del invencible cavallero Amadís de Gaula, por Servaes Sassenus, concebida para su consumo por los mercaderes, estudiantes y cortesanos españoles, que, ya por entonces, residían en gran número en las ciudades de Flandes y Brabante. La reina María de Hungría, hermana de Carlos Vy gobernadora de los Países Bajos, adquirió la colección completa en francés del Amadís, que se citan en el inventario redactado a su muerte en Cigales (1558), por separado, como «Yten, otro en tablas de papel e laços de oro e otros colores y la ymagen de nuestra señora en la vna y la cifra de vn coraçon en la otra, es el noueno libro de amadis d'español en françes» y tras el que añade más abajo "Yten, otro tal los doçe libros del amadis en françes» ${ }^{34}$. Se trata, como es evidente, de ejemplares de los 
diferentes volúmenes del Amadís en francés, cuya publicación fue iniciada en 1540 por Deny Janot y continuada después por Étienne Groulleau. Las magníficas xilografías que lo ilustran deben ser puestas en relación directa con las caballerescas fiestas de Bins, o Binche, que la reina María organizó para celebrar la llegada del príncipe Felipe a los Países Bajos en 1549, y en donde éste participó como el gran protagonista, interpretando el papel del caballero Beltenebros. Estos libros fueron heredados por Felipe II, permaneciendo en la biblioteca del Alcázar hasta su muerte. En 1574 son citados en un inventario de los libros del rey de esta manera:

\author{
Los quatro primeros de Amadis \\ E1 5 y 6 y 7 de Amadis \\ El $8^{\circ}$ de Amadis \\ El noueno de Amadis, falta el dezeno y el onzeno \\ El dozeno de Amadis \\ Otro libro sexto de Amadis \\ Otro libro septimo de Amadis ${ }^{35}$.
}

En 1598, al fallecer Felipe II, entre sus libros todavía figuraban «Siete libros yn folio en françes ympressos en paris enquadernados en cuero colorado y de colores de la Historia de Amadis de guala (sic)", que fueron entregados a Hernando Espejo para ser vendidos en almoneda ${ }^{36}$. Llama la atención, su magnífica encuadernación al mâstic ("cuero colorado y de colores») que presentaban estos libros, una cubierta de lujo que explicaría, junto con sus magníficas ilustraciones xilográficas, que estos ejemplares no fueran desechados por el rey o por sus criados. Este fue uno de los destinos habituales para los libros de caballerías en esta época, y no sólo tras morir sus dueños. En el inventario de 1574 de Felipe II no había ya rastro algunos de sus libros de caballerías en castellano, adquiridos en 1547 . Perdida su utilidad, probablemente fueron prestados, vendidos o destruidos.

También el príncipe don Carlos, hijo de Felipe II, tuvo varios libros de caballerías en su cámara. Sabemos que en 1558 se le compró el libro cuarto del Amadis. Poco después se registra la adquisición de otros «dos libros de cauallerias» (los libros undécimo y decimotercero del Amadís), si bien se dice que se llevaron para unas damas ${ }^{37}$. Se trataba de ejemplares de ediciones del Florisel de Niquea. No se dice en la libranza palatina quiénes fueron estas afortunadas damas, pero es de suponer que estuvieran al servicio de la princesa Juana de Austria, tía de Carlos. En las mismas cuentas se anota fugazmente la adquisición de «los quatro de amadis de los de

35.- Libros en francés y en folio a cargo de Juan de Serojas (1574). Real Biblioteca del Monasterio de El Escorial, Ms. \&-II-15, fol. 309r.

36.- Inventario de Felipe II (agosto de 1597). Biblioteca Zabálburu, Altamira, carpeta 104, fol. 75 , item $n^{\circ} 209$.

37.- Libranza a Pedro Ordóñez desde el 17 de julio de 1557 al 15 de marzo de 1558. Archivo General de Simancas, Contaduría Mayor de Cuentas, $1^{a}$ época, leg. 1121, s/f. 
anberes en dos cuerpos jaspeado y dorado el cuero", una cita que poco después fue tachada, con una nota al margen "heredia», quizás porque le fueran regalados. Sobre esta referencia, llama la atención que en 1558 se cite Amberes como la ciudad de procedencia de los ejemplares, pues Cristobal Plantino no imprimió el Tresor des Amadis, o su primera edición en francés de los libros del Amadís, hasta 1560 y 1561 respectivamente. Creemos que se trata de una confusión del criado principesco, y que la anotación se refiere a la citada edición impresa en Lovaina (1551), por Servaes Sassenus, pues al pie de la portada se informaba que los ejemplares se vendían «en Enberes, en casa de Arnoldo Byrckmanno a la enseña de la gallina gorda». De aquí la confusión.

Terminaremos nuestro periplo por los inventarios de los miembros de la familia real con la reina Isabel de Valois. Tanto ella como sus damas fueron unas lectoras, casi podríamos decir que compulsivas, de los libros de caballerías, y esto a pesar de que durante el reinado de Felipe II la producción de estas obras decayó notablemente, tanto en cantidad como en calidad Alvar y Lucía Megías (2000). Para la tercera esposa del monarca, hija del rey de Francia, sin embargo, se compró una amplia y selecta colección de obras caballerescas. En 1560 el conde de Alba de Liste, mayordomo de la reina, mandó comprar en Toledo «los quatro libros de Amadis para Su Magd., que costaron quarenta reales» ${ }^{38}$. En 1563 se compararon para la reina otros siete libros de caballerías. No se detallan los títulos, pero es probable que se tratara de un juego con el resto del ciclo amadisiano, que incluiría las partes del Florisel de Niquea. Al año siguiente, Isabel de Valois mandó adquirir los cuatro libros de Amadís de Gaula en francés, al precio de 33 reales, y poco después una de sus damas, Estefanía Manrique, compró para la reina un «Don Florís» — título que González de Amezúa (1949: 246-248) identifica con el Florisel de Niquea- a un precio de 22 reales. No obstante, la denominación del libro, tan a la italiana, nos hace suponer que se trataba del ejemplar de una edición en esta lengua. No en vano, cuando la reina murió se pusieron en almoneda cuatro volúmenes del Amadís, en italiano que se vendieron por 55 reales: "Se rremataron en Juan de la Guerra, camarero del Marqués de Montes Claros, quatro cuerpos de libros de la Ystoria de Amadis, scriptos en lengua ytaliana, en 55 reales» (González de Amezúa, 1949: III, 557). Los libros no se conservaron para sus hijas, las infantas Isabel Clara Eugenia y Catalina Micaela, quizás porque no eran lecturas apropiadas para niñas de su edad.

No en vano, los volúmenes adquiridos para su progenitora se seleccionaron para ayudar a mitigar su aburrimiento, y el de sus damas. Como ya sabemos, los libros de caballerías solían ser muy requeridos por las damas palatinas, a pesar de las prevenciones que contra ellos manifestaban los

38.- Archivo General de Simancas, Casa y Sitios Reales, leg. 41, 1383r. Comprados en Toledo el 11-jul-1560. 
moralistas. En 1567 se registra el alquiler de varios libros de caballerías y otros sin especificar, que el barrendero Pedro de Valdivieso buscó en las librerías madrileñas para la reina y sus damas ${ }^{39}$. Por un lado, en abril de 1567 , se indica que hay que pagarle al barrendero «doze rreales que an costado çiertos libros de cavallerías que las damas an alquilado» (Bouza, 1996: 41) y, por otro, en un recibo de mayo de ese año se paga al mismo Valdivieso «doze rreales que costó de alquilar un libro del cavallero del febo que tuvieron las damas cierto tiempo» (González de Amezúa, 1998: I, 247). En aquellos meses de primavera la reina estaba embarazada de nuevo (en febrero se dio a conocer la feliz noticia), por lo que se comprende la necesidad de entretenerse que las damas tenías durante las largas jornadas en reposo que su señora debía guardar. Tales lecturas hicieron de las mismas unas consumadas conocedoras de los argumentos y personajes caballerescos, conocimientos que volcaron en otras actividades, como las teatrales, o las epistolares. Con respecto a lo primero, es sabido que se organizaron unas máscaras en el alcázar madrileño el día de Reyes de 1564, y que la de la reina versó sobre un pasaje del Amadís de Grecia de Feliciano de Silva, concretamente el episodio en el que el hada Cirfea encanta a Niquea. Con relación a lo segundo, es bien conocida la elegante correspondencia mantenida, hacia 1572, entre Magdalena de Bobadilla, dama de Juana de Austria, y Juan de Silva, conde de Portalegre, bajo los seudónimos de Corisandra y Florestán, unas epístolas en estilo caballeresco en las que ambos tomaron como referentes episodios y personajes procedentes de los cinco primeros libros del Amadís.

Si en palacio, los reyes, reinas y príncipes compraban y leían libros de caballerías, la misma presencia de estas obras se detecta de manera muy importante entre sus propios cortesanos. Según el estudio realizado por Priego Bernabé (2004: I, 278-279) la mayoría de los dueños de libros de caballerías eran miembros de la nobleza, calculando en 30 \%. A la aristocracia le seguiría el funcionariado, con el $20 \%$, y las profesiones liberales y el clero con el $17 \%$ cada uno. El resto, un 13\% estaba representado por artesanos, mercaderes y personas sin profesión definida. El predominio de los nobles como lectores de libros de caballerías no se debía tan solo a su mayor capacidad adquisitiva, lo que les permitía comprar los caros libros impresos en folio que se ponían a la venta en el siglo XVI, ni tampoco a que podían disponer de mayor tiempo de ocio para este tipo de lecturas. No, su principal motivación estuvo en el creciente papel que la literatura caballeresca tuvo en la conformación de la civilización cortesana renacentista. Los nobles leían la amplia panoplia de Amadíses, Palmerines, Primaleones, Floristanos y Esplandianes, que los impresores ponían a la venta, porque las reglas de la caballería que en estas obras se ensalzaban eran las mismas que ellos debían seguir en la Corte. Se produ- 
jo una notable simbiosis entre la sociedad palatina y la literatura caballeresca. No vamos a desarrollar esta cuestión, pero pongamos un ejemplo para ejemplificar esta cuestión. ¿Cómo podía participar un noble con el suficiente decoro y propiedad en fiestas cortesanas, como las celebradas por el bautizo de Felipe II, en Valladolid (1527), o en las de Binche (1549), si desconocía los argumentos del Amadís de Gaula? La nobleza, por tanto, fue una ávida e interesada lectora de las ficciones caballerescas, que se podían entender además como "espejos", es decir, como obras con una finalidad pedagógica, a la par que lúdica. Algunos de sus autores, como Feliciano de Silva o Herberet de Essarts eran nobles, por lo que se entendía que escribían para sus iguales, y las dedicatorias de sus obras a otros aristócratas cerraba el círculo de una literatura dotada de una notable apariencia nobiliaria. Como destaca Lucía Mejías, cuando en 1564 se reedita el Amadís de Grecia, de Feliciano de Silva, en el taller vallisoletano de Francisco del Canto, el librero Benito Boyer, encomendó la magnífica edición a Pedro de Morejón, caballero de Santiago, concluyendo su dedicatoria con estas significativas palabras:

Viendo pues yo que por descuido de los impressores passados casi estava olvidada una obra de tanta erudición, quise, aunque a gran costa de mi trabajo, sacarla a luz. Y porque para salir con tan alta empresa mis fuerças son pocas, determiné atreverme a las de V. M. como a tan mi señor, porque debaxo de sus alas y amparo estará mi buena intención segura de los maldizientes. La obra es de cavallero, y tan insigne como Feliciano de Silva, y no menos la sería la de V. M. en recibirla debaxo de su tutela y amparo, pues en $\mathrm{V}$. M. se halla tan cumplida virtud, cavallería, y maduro consejo; y aunque el servicio sea pequeño, resciba V. M. la voluntad.

Y siguiendo las palabras de Boyer, bajo la tutela y amparo de muchos nobles llegaron los libros de caballerías a sus bibliotecas. Uno de los primeros aristócratas castellanos que leyó a Feliciano de Silva fue don Rodrigo de Mendoza, marqués del Cenete. Éste poseía a su muerte en 1523 un ejemplar de El séptimo libro de Amadís de Gaula, es decir, del mismo Lisuarte de Grecia que Feliciano de Silva había publicado, de manera anónima, en 1514. Si solo dos años antes la misma obra ya había llegado a la isla de santo Domingo, en las Antillas, no ha de sorprender que lo tuviera también en sus manos este noble, asentado en Valencia. No eran, sin embargo, muchos los libros de caballerías que tenía Rodrigo de Mendoza, lo que tiene cierta lógica ya que el género había iniciado su andadura poco antes, con el Amadís publicado en 1508. El marqués de Cenete prefería leer otras piezas de prosa caballerescas tradicionales, como la Crónica del rey don Rodrigo de Pedro del Corral, la Poncella de Francia, dos ejemplares 
de La historia del emperador Carlomagno y de los doce pares, algunas crónicas caballerescas no identificadas, diversos tratados militares y algunas composiciones sobre Alejandro Magno (Sánchez Cantón, 1942).

En la misma ciudad de Valencia los inventarios de otros nobles nos permiten percibir cómo la cantidad de obras se fue incrementado de manera paulatina, pero constante, a lo largo de la primera mitad del Quinientos. Si el marqués de Cenete sólo tenía un ejemplar del Lisuarte, su hija y heredera Mencía de Mendoza, en cambio, incrementó con un par de obras la colección. En su biblioteca de 949 volúmenes (entre los que heredó el Lisuarte de su padre), no sólo había un gran número de textos humanísticos y de literatura greco-latina, sino que también contuvo un número notable de obras en romance. Entre ellas se hallan algunos de narrativa caballeresca, como un Lanzarote en prosa, que debemos suponer en su lengua original, y por supuesto, un ejemplar del Valerián de Hungría, el libro de caballerías que el notario valenciano Dionís Clemente dedicó a la marquesa en $1540^{40}$. Doña Mencía no fue un ejemplo representativo de la lectura femenina nobiliaria de libros de caballería, aspecto que se corresponde con su propio perfil cultural, pues fue discípula de Juan Luis Vives, uno de los grandes detractores de la literatura caballeresca, sin embargo, no parece que despreciara por completo su lectura.

De quien no hay duda sobre su predilección acerca de los libros de caballerías fue su segundo marido, Fernando de Aragón, duque de Calabria y virrey de Valencia, con quien contrajo segundas nupcias en 1541. Este noble italiano, último descendiente varón la de la dinastía aragonesa que había gobernado Nápoles tras la conquista de Alfonso V el Magnánimo, era también un noble culto y un gran bibliófilo, que a su muerte (1550) tenía en su biblioteca una amplia colección de obras caballerescas, muchas duplicadas: Los cuatro libros de Amadís, el Palmerín de Olivia, un Don Leonís de Grecia, obra de la que no se conserva ejemplar alguno, el Valerían de Hungría, dedicado a su esposa, un ejemplar del Lucidante de Tracia, libro perdido, pero registrado por Hernando Colon, Las Sergas de Esplandián, VI de Amadis [Florisando], Los cuatro libros de Clarián, Félix Magno, Florambel, los dos libros de Espejo de Caballerías, el cuarto de don Reinaldos, Trapisonda, Lidamor, El caballero de la Rosa y, como no podía ser de otra manera, los libros compuestos por Feliciano de Silva, el libro VII de Amadís [Lisuarte de Grecia] y el X del Amadís [Florisel de Niquea] ${ }^{41}$. Sorprende, sin embargo, que careciera en su biblioteca de la siguiente continuación amadisiana de Silva, es decir, el libro XI, parte III, impresa en 1535 y en 1546, no de la parte IV, dedicada a María de Austria, impresa en 1551, muerto ya el Duque. Quizás se debiera a la existencia de una serie de libros de caballerías valencianos, Floriseo, Arderique, Claribalte, Va-

40.- Véase Duce García (2017), Clemente (2010) y Marín Pina (1991b).

41.- Véase Repullés (1874) y Duce García (2017). 
lerián de Hungría, Lepolemo, herederos en cierta forma del Tirant lo Blanc, con un perfil diferenciador que Sales Dasí (2007) denomina la "conexió cavalleresca valenciana». En todo caso, la predilección que los inventarios del duque de Calabria muestran por la literatura de caballerías era consecuente con el ambiente lúdico de su Corte valenciana, en la que se representaron máscaras, farsas, motes y momos de clara imitación italiana, así como torneos amorosos y justas reales, en los que la impronta de la saga de Amadís fue muy notable, participando Luis Milán en algunas de estas farsas como el caballero errante Miraflor de Milán.

Si nos trasladamos a Castilla, los inventarios nobiliarios nos proporcionan un panorama distinto y muy interesante. En Valladolid, durante el reinado de Carlos V, nos encontramos con los inventarios de los libros de Cristóbal († c. 1536) y Francisco de Santiesteban. Regidores de esta ciudad, padre e hijo reunieron una interesante colección de libros de caballerías, que acabaría heredando la nieta e hija de ambos, Isabel de Santiesteban. En los inventarios de sus bienes recibidos por ésta de su padre, realizados entre 1548 y 1552, entre los 67 títulos referenciados aparecen copias manuscritas del Amadís, de la Demada del santo Grial y del Lanzarote, así como ejemplares impresos del Amadís (los cuatro primeros libros), del Palmerín, del Lancelot en francés, del Espejo de caballerías, del Florambel de Lucea, y, como no podía ser de otra manera, un ejemplar de "Don Florisel de Niquea", tasado en tres reales (Cátedra y Rojo Vega, 2004: 234, nota 56). Pero su abuelo y padre no solo eran amantes de los libros de caballerías, el primero fue también editor de los mismos. La presencia de varios ejemplares manuscritos puede dar a entender que se trataba de copias bajomedievales, $y$, en consecuencia, que nos encontramos ante una biblioteca más propia de la transición entre los siglos XV y XVI que de mediados de esta segunda centuria, pero se trataba probablemente de originales manuscritos para la imprenta, pues en 1527 Cristóbal de Santiestaban logró un privilegio de impresión, para imprimir «los libros de Erodiano y el Lucano y el Dorosiculo y los tres libros de Lançarote del Lago y el grand baladro de Merlin y el libro de los qüentos» ${ }^{42}$. Por contraste, citaremos el inventario de los libros de Fadrique Álvarez de Toledo, duque de Alba (1531), un noble con amplia trayectoria militar, conocido por su lealtad al rey Fernando el Católico, y del que a su muerte no se encuentran libros de caballerías entre sus bienes, a pesar de que se trata de una biblioteca bastante extensa, con 186 items (Bustos Tauler y Sanmartín Bastida, 2016). Las lecturas de crónicas le eran mucho más gratas.

En algunas bibliotecas de mujeres de la nobleza, sin embargo, resulta más habitual encontrar libros de caballerías. En esto hay una clara coincidencia con las damas de la Corte de la emperatriz Isabel o de la reina Isa-

42.- Privilegio publicado por Juan Meseguer (1970: 221). Sobre este privilegio y la edición del Baladro véase Cátedra y Rodríguez Velasco (2000: 86-89). 
bel de Valois. Feliciano de Silva tuvo, además, muy en cuenta la recepción de sus obras por parte del público femenino. Puede considerarse como paradigmática a este respecto la pequeña biblioteca (15 libros) de Eufrasia de Arteaga (1558), estudiada por Pedro Cátedra (2004). Viuda de Pedro de Carrión, escribano y receptor de la Chancillería de Valladolid, esta dama tenía casi todos los libros de caballerías de la época, como ejemplares de Silves de la Selva, de Pedro de Luján, Clarán de Landanís, de Gabriel Velázquez del Castillo, el Palmerín de Oliva, o un Don Roldán de Grecia (quizás el Rogel de Grecia), sin que faltaran en su casa ejemplares de los obras de Silva, como uno de "La primera parte de Amadís de Grecia» y "otro libro quarto de don Florisel de Niquea». Cátedra identifica ambos con las ediciones respectivas de Cuenca (1530) y Salamanca (1551). Si así fuera, y en este segundo caso parece haber poca duda, doña Eufrasia había adquirido la misma obra que Silva dedicara a María de Austria pocos años antes. En 1570, cuando se realizó el inventario de los bienes de Catalina de Silva y Andrade, viuda del conde de Melito, se hallaron unos trescientos libros, entre los que había unos veinte de caballerías: Amadís de Gaula, Amadis de Grecia, Primaleón, Reinaldos de Montalbán, Tirante el Blanco, Palmerín de Olivia, dos ejemplares del Florisel de Niquea y La primera parte de la cuarta de la crónica de don Florisel de Niquea, La cuarta de don Florisel de Niquea, El séptimo libro de Amadís, Amadís de Gaula, el tercero de volumen, dos ejemplares de El caballero de la Cruz, otro . Amadís de Gaula y Los cuatro libros de Amadís de Gaula ${ }^{43}$, ejemplares que probablemente heredó su hija, Ana de la Cerda y Mendoza, la princesa de Éboli. A ésta, durante su prisión en Pinto por orden de Felipe II, se le autorizó la lectura de los cuatro libros de Amadís de Gaula y de dos ejemplares del Florisel de Niquea, de Feliciano de Silva.

Durante el reinado de Felipe II los libros de caballerías se encuentran en gran parte de las bibliotecas nobiliarias. Al fallecer el Duque de Sessa en 1578, en la almoneda se pusieron a la venta varios de sus libros de caballerías, como "Otro libro de olibante de laura» (9 reales) y "Otro libro del cavallero del phebo" (4 reales) $)^{44}$, y cuando en 1603 murió Alonso Diego López de Zúñiga, duque de Béjar, en el inventario de sus libros se registró la presencia de una amplia colección, entre cuyos volúmenes las obras de Feliciano de Silva tenían una importante presencia: "Otro libro titulado la Primera parte de Belcanís de Grecia, enquadernado en pergamino blanco, con los escudos de la casa", "Otro titulado Don Florisel de Niquea, enquadernado en pergamino blanco", "Otro titulado la Ystoria de don Cristalián d[e] España, enquadernado blanco", "Otro titulado Segunda Parte de Don Florisel de Niquea» y, por último, "Otro, la Primera Parte de Don Florisel de Niquea». A este respecto quizás sea bueno recordar que Silva dedicó a Francisco de Zúñiga de Sotomayor, tercer duque de Béjar, la Cuarta parte

43.- Su presencia ha sido estudiada por Dadson (2011) y Vilches Fernández (2017).

44.- Biblioteca Zabálburu, Altamira, 34, D. 71. Se remataron el 9 de enero de 1579. 
de Florisel de Niquea. Esta predilección por las obras caballerescas de Feliciano de Silva la encontramos también en la biblioteca de Alonso Osorio, marqués de Astorga. Como en el caso anterior, este tipo de literatura era muy del gusto de los Osorio, en especial de Pedro Álvarez Osorio († 1560), IV marqués de Astorga, a quien su secretario Francisco Enciso de Zárate dedicó un par de libros de caballerías: Florambel de Lucea (1532) y Platir (1533). Su hijo, el citado don Alonso Osorio, fue muy aficionado a las hazañas literarias de los sucesores del Amadís. En el denominado por Pedro Cátedra (2002) como Inventario A (1573), se recogen ejemplares del Lisuarte de Grecia, de La crónica de los muy valientes y esforzados y invencibles cavalleros Don Florisel de Niquea y el fuerte Anaxartes, de La primera parte de la cuarta de la crónica del excelentísimo principe Don Florisel de Niquea, y de La segunda parte de la cuarta crónica del excelentísimo Príncipe don Florisel de Niquea, entre otros libros de caballerías que, de manera sorprendente, desaparecen en el siguiente inventario de 1593. Se ha atribuido esta ausencia a un cambio en los gustos lectores del marqués de Astorga.

Quien, sin embargo, no abandonó su predilección por los libros de caballerías fue Diego Sarmiento de Acuña, conde de Gondomar. En 1623, en la Casa del Sol, su residencia vallisoletana, tenía dieciséis libros de caballerías, según su inventario con muy diferente procedencia y cronología. Entre estos libros había las siguientes obras de Feliciano de Silva: "Chronica de Don Florisel de Niquea y el fuerte Anaxartes. Çaragoça, 1584, f.», "Tercera parte dela Chronica de Don Florisel de Niquea, f.». "Chronica de Lisuarte de Grecia y de Perion de Gaula. Çaragoça, 1587, f.», así como alguna de sus ediciones en italiano: unto a los castellanos, las traducciones italianas también van a gozar de una considerable presencia en la Casa del Sol, en total suman nueve entradas: "Aggiunta al secondo volume di Don Rogello di Grecia. Venetia, 1564, 8. "», "Don Florisando et le sue gran proddezze. Venetia, 1550, 8. „ (Lucía Megías (2003).

Concluiremos nuestro periplo con la presencia de las obras de Feliciano de Silva entre el clero de origen noble. No parece que fuera desdeñable la lectura de libros de caballerías, y esto a pesar de las reiteradas admoniciones morales y prohibiciones legales que a lo largo del siglo XVI se lanzaron en contra de la lectura de libros de caballerías. Estas contradicciones también se trasladan a los inventarios de libros de miembros del clero que hemos analizado. Hernando Colón, por ejemplo, bibliófilo y canónigo de la catedral de Sevilla, no despreció la adquisición de libros de caballerías. Bien es cierto que su propósito era el de reunir una auténtica biblioteca universal de libros impresos, y que sus Registros y Abecedarios son catálogos, y no tanto inventarios, pero son una fuente inestimable para seguir de manera cronológica la recepción de los libros de caballerías en su biblioteca. Estudiados por Klaus Wagner (1998), las primeras ediciones que compró fueron, en Valladolid, unas Sergas de Esplandián, un Florisardo y el "sexto lib. del Amadís», en septiembre de 
1514. Solo unos meses después, en noviembre, y en la misma ciudad adquirió un ejemplar del Lisuarte de Grecia, el primer libro de caballerías publicado por Silva. Como fue impreso en Sevilla ese mismo año, con el título de El séptimo libro de Amadís de Gaula, que trata de los grandes fechos en armas de Lisuarte, se comprende su interés en adquirir la continuación del sexto, pero también llama la atención de que esta edición, con colofón fechado el 22 de septiembre de 1514, ya estuviera a la venta en Valladolid solo dos meses después. Este apunte en el Registrum $B$ nos revela la rapidez en la difusión comercial de esta obra. Colón adquiriría más tarde el resto de las continuaciones del Amadís, compuestas por Silva: Amadís de Grecia, publicado en 1530, Florisel de Niquea (1532) y Rogel de Grecia (1535). Al fallecer en 1539, el hijo del Descubridor disponía en su biblioteca de toda la producción completa de este autor.

¿Participaban de este interés por los libros de caballerías otros canónigos sevillanos? Si avanzamos hacia el reinado de Felipe II, su secretario Mateo Vázquez de Leca, criado en Sevilla, arcediano de Carmona y canónigo de su catedral, carecía en su biblioteca de libros de caballerías. Sus gustos literarios, como es sabido, se orientaban más hacia la poesía y el género pastoril, sin desdeñar la gran obra de la poética caballeresca, pues en los inventarios de su biblioteca (de 1579 y 1581) aparecen tres ejemplares del Orlando furioso de Ariosto, en italiano (Gonzalo Sánchez Molero, 2014). Pero evidentemente no desconocía la temática caballeresca. Confiesa en 1584 a su amigo Hernando de Vega: «... pienso, si Dios se estuviere de boluerme aí con vida, procurar desoccuparme y algunos ratos a las tardes que v. s. salga al campo yrle a seruir de escudero y descansar mucho en esto de los trabajos y aflicciones con que se passa esta amarga vida» ${ }^{45}$. Cuando en 1581 el cosmógrafo Juan López de Velasco le ordenó su biblioteca madrileña, mientras Vázquez estaba en Portugal, la ausencia de libros de caballería no le preocupó, pero sí le aconsejó que completara sus lecturas poéticas en castellano adquiriendo las obras de Garcilaso, Torres Naharro, Castillejo y Lucano.

En una actitud opuesta encontramos a García de Loaysa, otro clérigo cortesano, bien conocido por Mateo Vázquez. Como ya pusiera de manifiesto Juan Carlos Rodríguez Pérez (2018), García Loaysa sería maestro del futuro rey Felipe III y breve arzobispo de Toledo, tenía a su muerte (1599) una extensa colección de libros de caballerías. Como es sabido, a lo largo de toda su vida don García fue desarrollando una gran biblioteca, compuesta por más de 4.000 volúmenes ${ }^{46}$, algunos de ellos auténticas obras de arte, además de libros raros o, incluso, prohibidos por

45.- Mateo Vázquez a Hernando de Vega (San Lorenzo de El Escorial, 5 de agosto de 1584). Biblioteca Zabálburu, Altamira, carpeta 140. GD. 1, doc. 33/2.

46.- El Ynbentario y secresto de bienes de el señor arçobispo de Toledo, don García de Loaysa Girón, de los que avia al dicho de su muerte en Madrid, Archivo Histórico de Protocolos de Madrid (AHPM), Protocolo 1811, fols. 1495r y siguientes. 
la Inquisición. Ente ellos aparecen los principales caballeros andantes, como Amadís, Belianís, Lisuarte, Palmerin, Esplandián, Olivante de Laura, Primaleón, El Caballero del Febo, Cristalián, Florisel o Amadís de Grecia. Pudiera pensarse que se trataba de libros heredados, por ejemplo, de su padre, Pedro Girón, un cortesano de Carlos V, pero, como bien advierte Rodríguez Pérez (2018: 145): «en muy pocos casos encontramos más de un ejemplar de cada uno de ellos, y casi siempre en otras lenguas, no en castellano. Solo en un caso no se cumple lo anteriormente dicho, pues el Amadís de Gaula se encuentra representado en la biblioteca en distintas ediciones e idiomas». Era, pues, en nuestra opinión el tratamiento lingüístico de estas obras lo que interesaba a García de Loaysa, un humanista y un erudito políglota. Identificar las ediciones resulta complicado, al no citarse en el inventario, pero los libros que tenía de Silva como autor eran los siguientes, todos en castellano:

[3108] Un caballero de la ardiente espada se tasó en diez y seis reales.

[3109] Una primera y segunda de don florises de niquea terzera y cuarta parte en tres cuerpos se tassó en veynte y cuatro reales.

[3122] Un lisuarte de greçia se tasó en seis rreales. (Rodríguez Pérez, 2018: 153 y 155)

A García de Loaysa se le podría aplicar un perfil semejante al que el propio Cervantes refleja en el Quijote. No olvidemos que es el cura quien, durante el donoso escrutinio de la biblioteca de Alonso Quijano, realiza la censura y crítica de los libros, mostrando un extraordinario conocimiento acerca de la literatura caballeresca. Es verdad que su criterio es que la mayor parte de los volúmenes se echen al fuego, pero al mismo tiempo, si tan mala opinión tenía de ellos frente a la del barbero, ¿cómo era tan experto en sus contenidos?:

Y el primero que maese Nicolás le dió en las manos, fue los cuatro de Amadís de Gaula, y dijo el cura: parece cosa de misterio esta, porque, según he oído decir, este libro fue el primero de caballerías que se imprimió en España, y todos los demás han tomado principio y origen de este; y así me parece que como a dogmatizador de una secta tan mala, le debemos sin excusa alguna condenar al fuego. No, señor, dijo el barbero, que también he oído decir que es el mejor de todos los libros que de este género se han compuesto, y así, como a único en su arte, se debe perdonar. Así es verdad, dijo el cura, y por esa razón se le otorga la vida por ahora. Veamos ese otro que está junto a él. Es, dijo el barbero, Las sergas de Es- 
plandián, hijo legítimo de Amadís de Gaula. Pues es verdad, dijo el cura, que no le ha de valer al hijo la bondad del padre; tomad, señora am, abrid esa ventana y echadle al corral, y dé principio al montón de la hoguera que se ha de hacer. (Quijote, I, VI)

El cura se mueve entre esta actitud ambivalente, pero se delata ante el Barbero y el Licenciado cuando cae al suelo un ejemplar de Tirante el Blanco, y entonces exclama:

Válame Dios dijo el cura, dando una gran voz; ique aquí
esté Tirante Blanco! Dádmele acá, compadre, que hago
cuenta que he hallado en él un tesoro de contento y una
mina de pasatiempos. Aquí está don Kirieleison de Mon-
talván, valeroso caballero, y su hermano Tomás de Mon-
talván y el caballero Fonseca, con la batalla que el valiente
de Tirante hizo con Alano, y las agudezas de la doncella
Placerdemivida, con los amores y embustes de la viuda
Reposada, y la señora emperatriz enamorada de Hipólito
su escudero. Dígoos verdad, señor compadre, que por su
estilo es este el mejor libro del mundo; aquí comen los
caballeros, y duermen y mueren en sus camas, y hacen
testamento antes de su muerte, con otras cosas de que
todos los demás libros de este género carecen. Con todo
eso, os digo que merecía el que lo compuso, pues no hizo
tantas necedades de industria, que le echaran a galeras
por todos los días de su vida. Llevadle a casa y leedle, y
veréis que es verdad cuanto de él os he dicho.

Si tenemos en cuenta los pasajes eróticos y amorosos que Joanot Martorell y Marti Joan de Galba introdujeron en el Tirant lo Blanc, sorprende que el cura lo tuviera en tan alta estima, y, sobre todo, que lo hubiera leído, como el maestro de Felipe III, García de Loaysa, también hiciera con otros muchos otros libros de caballerías. Retornando, para acabar con este periplo por la presencia de Feliciano de Silva en los inventarios de nuestro Siglo de Oro, cuando en 1593 se quiso enseñar francés al hijo del Rey Prudente, se decidió que aprendiera esta lengua Jean de L'Hermite, ayuda de cámara del propio rey desde 1590. En sus Memorias éste cuenta como todos los días, desde las dos hasta las cuatro de la tarde, y en presencia del Rey, se ocupaba en enseñar al Príncipe la lectura y pronunciación de textos en lengua francesa. Las lecciones se daban en presencia del propio monarca, sentándose su hijo en un pequeño escabel, y L'Hermite a su lado, con una rodilla en tierra. Y, según cuenta éste, se ayudó de la lectura del primer libro del Amadís de Gaula (una obra de la que Felipe II, como ya sabemos, heredó de María de Hungría una edición francesa casi comple- 
ta). El príncipe, sin embargo, se cansó pronto de esta lectura (L'Hermite, 1971). Y así parece que también lo pensaba Miguel de Cervantes.

\section{Bibliografía}

Alonso Cortés, Narciso (1933), "Feliciano de Silva», Boletín de la Real Academia Española, 20, pp. 382-404.

Alvar, Carlos y Lucía Megías, José Manuel (2000), "Los libros de caballerías en la época de Felipe II", en Isabel LozAno-Renieblas y Juan Carlos Mercado (eds.), Silva. Studia philologica in honorem Isaías Lerner, Madrid: Castalia, pp. 26-35.

Aguilar Perdomo, María del Rosario (2005), "La recepción de los libros de caballerías en el siglo XVI: a propósito de los lectores en el Quijote», Literatura: teoría, historia, crítica, 7, pp. 45-67.

BARAnDA, Consolación (1988) «Introducción» en Feliciano de Silva, Segunda Celestina, Madrid: Cátedra, pp. 25-102.

Bataillon, Marcel (1966), Erasmo y España. Estudios sobre la historia espiritual del siglo XVI, México: Fondo de Cultura Económica.

Bécares Botas, Vicente, e Iglesias, Alejandro Luis (1992), La libreria de Benito Boyer: Medina del Campo, 1592 (La imprenta, libros y libreros), Salamanca: Junta de Castilla y León. Consejería de Cultura y Turismo.

BÉCARes BotA, Vicente (2007), Librerías salmantrinas del siglo XVI, Segovia: Fundación Instituto Castellano Leonés de la Lengua.

Bognolo, Anna (2008), "Libros de caballerías en Italia», en Amadís de Gaula. 1508. Quinientos años de Libros de caballerías, Madrid: Biblioteca Nacional de España, Sociedad Estatal de Conmemoraciones Culturales, pp. 333-341.

BuceTA, Erasmo (1931), "Algunas noticias referentes a la familia de Feliciano de Silva», Revista de Filología Española, 18, pp. 390-392.

Bustos TÁuler, Álvaro y Sanmartín Bastida, Rebeca (2016), "Fadrique Álvarez de Toledo, II Duque de Alba y su inventario de libros (1531): una biblioteca patrimonial», Revista General de Información y Documentación, 26-1, pp. 273-290.

Cacho Blecua, Juan Manuel (1979), Amadís: heroísmo mítico-cortesano. Cupsa, Madrid.

Cátedra, Pedro. M. y Rodríguez Velasco, Jesús (2000), Creación y difusión de "El baladro del sabio Merlín» (Burgos, 1498), Salamanca: Semyr.

Cátedra, Pedro M. (2002), Nobleza y lectura en tiempos de Felipe II. La biblioteca de don Alonso Osorio marqués de Astorga, Valladolid: Junta de Castilla y León, Consejería de Educación y Cultura, 2002. 
Cátedra, Pedro M. y Rojo Vega, Anastasio (2004), Bibliotecas y lecturas de mujeres. Siglo XVI, Salamanca: Instituto de Historia del libro y de la lectura.

Cayuela, Anne (2005), Un librero en el Madrid de los Austrias, Madrid: Calambur.

CHARTIER, Roger (1994), El orden de los libros: lectores, autores, bibliotecas en Europa entre los siglos XIV y XVIII, Barcelona: Gedisa.

CheValier, Maxime (1976), Lecturas y lectores en la España de los siglos XVI y XVII, Madrid; Turner.

Clemente, Dionis (2010), Valerián de Hungría, ed. Jesús Duce García, Alcala de Henares: Centro de Estudios Cervantinos.

Cotarelo y Mori, Emilio (1921), «Nuevas noticias biográficas de Feliciano de Silva", Boletín de la Real Academia Española, 13, pp. 126-139,

Cravens, Sidney P. (1976), Feliciano de Silva y los antecedentes de la novela pastoril en sus libros de caballerías, Madrid: Estudios de Hispanófila.

DaDson, Trevor J. (2011), "The Education, Books and Reading Habits of Ana de Mendoza y de la Cerda, Princess of Éboli (1540-1592)», en Anne J. CRUZ y Rosilie HERNÁNDEZ (eds.), Women's Literacy in Early Modern Spain and the New World, Aldershot (UK) / Burlington (VT), Ashgate, pp. 79-102.

- (1998), Libros, lectores y lecturas. Estudios sobre bibliotecas particulares españolas del Siglo de Oro, Madrid: Arco/Libros.

Derolez, Albert (1979), Les catalogues de bibliothèques, Turnhout: Brepols.

DíAz, Furio (1972), "Le stanchezze di Clio. Appunti su metodi e problemi della recente storiografia dell'Ancien Regime in Francia", Rivista storica italiana, 84, pp. 683-745.

- (1966), "Metodo quantitativo e storia delle idee», Rivista storica italiana, 78, pp. 933-947.

Díez Borque, José María (2016), Bibliotecas y clase social en la España de Carlos V (1516-1556), Gijón: TREA.

- (2015a), Bibliotecas y librerías en la España de Carlos V, Barcelona: Calambur.

- (2015b), Bibliotecas y librerías en la España de Carlos V, Barcelona: Calambur.

Díez Boroue, José María (2012), Literatura, bibliotecas y derechos de autor en el Siglo de Oro (1600-1700), Madrid: Iberoamericana.

Díez Boraue, José María (2010), Literatura (novela, poesía, teatro) en las bibliotecas particulares del Siglo de Oro español (1600-1650), Madrid: Iberoamericana.

- (2008), «Novelas a la venta en librerías españolas del Siglo de Oro (1600-1650)», Bulletin Hispanique, 110, 1, pp. 91-109.

- (2007), "Bibliotecas y novela en el Siglo de Oro», Hispanic review, 2, pp. 181-203. 
Duce García, Jesús (2017a), «La corte del duque de Calabria y la literatura caballeresca en la Valencia renacentista", Memorabilia. Boletín de literatura sapiencial, 19, pp. 17-63.

- (2017b), «Mencía de Mendoza y los libros de caballerías», Tirant, 20, pp. 25-36.

Eisenberg, Daniel y Marín Pina, María Carmen (2000), Bibliografía de los libros de caballerías castellanos, Zaragoza: Prensas Universitarias de Zaragoza, 2000.

Fernández Travieso, Carlota y Sagrario López Poza (2011), «IBSO (Inventarios y Bibliotecas del Siglo de Oro). Nueva base de datos en internet del grupo SIELAE», Etiópicas, 7, pp. 1-30.

García Álvarez, Juan Pablo Mauricio (2015a), «Narratividad teatral en Feliciano de Silva», en Carlos ALvar (coord.), Estudios de literatura medieval en la Peninsula Ibérica, San Millán de la Cogolla: Cilengua. Centro Internacional de Investigación de la Lengua Española, Instituto de Historia del Libro y de la Lectura, pp. 577-592.

- (2015b), «Alternativas narrativas para enlazar historias en la «Primera parte del Florisel de Niquea» (cap. VI-XXI», en Marta HARO CorTés (coord..), Literatura y ficción: "estorias", aventuras y poesía en la Edad Media, Valencia, Universitat de València, Servei de Publicacions, vol. 2, pp. 489-502.

GonZÁlez Sánchez, Carlos Alberto (1997), "Consideraciones sobre el comercio de libros en Lima a principios del siglo XVII", Anuario de Estudios Americanos, 54-2, pp. 665-692.

González de AmezÚa y Mayo, Agustín (1949), Isabel de Valois. Reina de España (1546-1568), Madrid: Gráficas Ultra 3 vols.

Gonzalo SánChez-Molero, José Luis (2015), «Libros y bibliotecas portátiles: la biblioteca del embajador Lope Hurtado de Mendoza y de su hija Luisa de Rojas (1531-1542)», en José María Díez Boroue (dir.), Bibliotecas y librerías en la España de Carlos V, Barcelona: Calambur Editorial, pp. 183-223.

- (2014), "Mateo Vázquez de Leca, un secretario entre libros. 2. La biblioteca", Hispania Sacra, 66, 1, pp. 35-65.

- (2013). Felipe II: la educación de un "felicísimo príncipe» (1527-1545), Madrid: CSIC.

Gonzalo Sánchez-Molero, José Luis (2005), Regia Bibliotheca. El libro en la corte española de Carlos V, Mérida: Editora Regional de Extremadura, 2 vols.

- (2000), «La biblioteca postrimera de Carlos V en España: las lecturas del emperador», Hispania: Revista española de historia, 60, 206, pp. 911-944.

- (1998), La "Librería rica" de Felipe II. Estudio histórico y catalogación, San Lorenzo de El Escorial: Real Colegio Universitario Escorial-Ma Cristina. Servicio de Publicaciones. 
Griffin, Clive (1998), «El inventario del almacén de libros del impresor Juan Cromberger: Sevilla 1540.» En Pedro Manuel CÁTEDRA GarCía y María Luisa LóPez-Vidriero Abello (coords.), El libro antiguo español. IV. Coleccionismo y bibliotecas (Siglos XV-XVIII), Salamanca: Ediciones Universidad de Salamanca, pp. 257-373.

- (1991), Los Cromberger: la historia de una imprenta del siglo XVI en Sevilla y Méjico, Madrid: Cultura Hispánica, 1991.

Griffin, Clive (1988), «Un curioso inventario de libros de 1528», en Pedro Manuel Cátedra García y María Luisa López-Vidriero Abello (coords.), El libro antiguo español: actas del Primer Coloquio Internacional, (Madrid, 18 al 20 de diciembre de 1986), Salamanca: Universidad de Salamanca, Ediciones Universidad de Salamanca, pp. 189-224.

INFANTES, Víctor (1999), "La memoria de la biblioteca: el inventario», en Pedro M. Cátedra, Augustin Redondo y María Luisa López-Vidriero (dirs.), El escrito en el Siglo de Oro: prácticas y representaciones, Salamanca, Universidad de Salamanca, pp. 163-170

- (1997), "Las ausencias en los inventarios de libros y de bibliotecas», Bulletin Hispanique, 99. Ejemplar dedicado a: Les Livres des Espagnols à l'Epoque Moderne, pp. 281-292.

KoHUT, Karl (2002), «Teoría literaria humanística y libros de caballerías», en Eva Belén Carro Carbajal, Laura Puerto Moro y María Sánchez PéREZ (eds.), Libros de Caballerías (de "Amadís" al "Quijote»). Poética, lectura, representación e identidad, Salamanca: Seminario de Estudios Medievales y Renacentistas. Sociedad de Estudios Medievales y Renacentistas, pp. 173-185.

LaY, Adriana (1990), "Libro y sociedad en los estados sardos del siglo XVIII", en A. Petrucci, (coord.), Libro, editores y público en la Europa moderna, Valencia, Edicions d'Alfons el Magnànim. Institució Valenciana d'Estudis i Investigació, pp. 247-277.

L'Hermite, Jean (1971), Les Passetems de Jehan de L'Hermite: Publie d'Apres le Manuscrit Original par Ch. Ruelens. Ginebra: Slatkine reprints.

LeONARD, Irving A. (1933), Romances of chivalry in the Spanish Indies (...) Berkeley: University of California.

Lucía MeGías, José Manuel (2003), «La biblioteca en la teoría de la lectura coetánea: los libros de caballerías del conde de Gondomar», en Castillo Martínez, Cristina y Lucía Megías, José Manuel (eds.), Decíamos ayer... Estudios de alumnos en honor a María Cruz García de Enterría, Salamanca: Universidad de Alcalá de Henares, pp. 251-284.

Lucía Megías, José Manuel (2000), Imprenta y libros de caballerías, Madrid: Ollero \& Ramos.

- (1998), «Libros de caballerías impresos, libros de caballerías manuscritos (algunas observaciones sobre la recepción del género editorial caballeresco)", en Rafael BeLtRÁn (ed.), Literatura de caballerías y origen de la novela, Valencia: Universitat de València, pp. 311-341. 
Marín PinA, Ma. Carmen (1991a), «Nuevos datos sobre Francisco Vázquez y Feliciano de Silva, autores de libros de caballerías», Journal Hispanic Philology, 15, pp. 117-130.

- (1991b), "La mujer y los libros de caballerías. Notas para el estudio de la recepción entre el público femenino", Revista de Literatura Medieval, 3, pp. 129-148.

Martín Lalanda, Javier (2002), "El ciclo de "Florisel de Niquea» [15321535-1551] de Feliciano Silva», Edad de Oro, 21, pp. 153-176.

Mira Caballos, Esteban (1994), "Algunas consideraciones sobre la primera biblioteca de Santo Domingo», Ecos, 3, pp. 147-154.

Meseguer, Juan (1970), "Documentos históricos diversos, siglos XIII-XVI», Archivo Ibero-Americano, 30, pp. 209-233.

Otero García, Mario Martín, (2010), «De Montalvo a Herberay des Essarts: el Amadís de Gaula en Francia, entre traducción y adaptación», en Literatura: teoría, historia, crítica, 12. Disponible en <http://www. revistas.unal.edu.co/index.php/lthc/article/download/20144/21231> [Consulta a 20 de octubre de 2018].

Pedraza Gracia, Manuel (1999), «Lector, lecturas, bibliotecas...: El inventario como fuente para su investigación histórica", Anales de Documentación, 2, pp. 137-58.

Prieto Bernabé, José Manuel (2004), Lectura y lectores: la cultura del impreso en el Madrid del Siglo de Oro (1550-1650), Mérida: Editora Regional de Extremadura, 2004, 2 vols.

Repullés, Manuel (1874), "Inventario de los libros de don Fernando de Aragón, duque de Calabria (a. 1550)», Revista de Archivos, Bibliotecas y Museos, 4, pp. 7-10, 21-25, 38-41, 54-56, 67-69, 83-86, 99-101, 114117, y 132-134.

Rodríguez Parada, Concepción (2007), "Los catálogos e inventarios en la historia del libro y de las bibliotecas", BiD: textos universitaris de biblioteconomia $i$ documentació, 18. (Disponible en internet: <http://bid. ub.edu/18rodri4.htm>. Accesible en red: <http://bid.ub.edu/18rodri4. htm> [Consulta: 23-01-2015].

Rodríguez Pérez, J. C. (2018). "Los caballeros andantes y el preceptor real. Libros de caballería en la biblioteca de García de Loaysa Girón (15341599)», en Cuadernos de Historia Moderna 43.1, pp. 133-156.

Sales Dasí, Emilio José (2007), Dels llibres de cavalleries a Blasco Ibáñez. La literatura cavalleresca a València, València, Institució Alfons el Magnànim.

- (2005), «El humor en la narrativa de Feliciano de Silva: en el camino hacia Cervantes», Literatura: teoría, historia, crítica, 7, pp. 115-157.

- (2004-2005), "Feliciano de Silva en el espejo de Feliciano de Silva», Letras. Libros de caballerías. El Quijote. Investigación y Relaciones, 50-51, pp. 272-295. 
SÁnchez Cantón, Francisco Javier (1942), La biblioteca del Marqués de Cenete, iniciada por el cardenal Mendoza (1470-1523), Madrid: CSIC.

SARMATI, Elisabetta (1996), Le critiche ai libri di cavalleria nel Cinquecento spagnolo: (con uno sguardo sul seicento) un'analisi testuale, Pisa: Giardini.

Silva, Feliciano de (1629), La historia di Amadis de Grecia, Cavallier dell'Ardente Spada: tradotta dalla spagnola, nella volgar lingua italiana. In Veneti: presso Gio. Battista Combi.

THOmas, Henry (1952), Las novelas de caballerías españolas y portuguesas, Madrid: C.S.I.C.

VilChes FeRnÁNDEZ, Rocío (2017), "La hermossa Isabella que presente está» (Claridoro de España): la princesa de Éboli y los libros de caballerías», Tirant, 20, pp. 147-160.

Wagner, Klaus (1998), "Los libros de caballerías y otras historias de aventuras en la biblioteca de Hernando Colón», en Pedro Ruiz Pérez (coord..), Cervantes y Andalucía: biografía, escritura y recepción: actas del Coloquio Internacional, Estepa, diciembre de 1998, Estepa (Sevilla), Ayuntamiento, pp. 25-53.

Zapata de Chaves, Luis (1949), Varia Historia (Miscelánea). Introducción, estudio, edición y notas de Isidoro Montiel. Madrid: Ediciones Castilla, 2 vols. 